\title{
Forbidden triads and innovation
}

\author{
Balazs Vedres \\ University of Oxford \\ Tunde Cserpes \\ Aarhus University
}

\begin{abstract}
This article investigates the importance of forbidden triads - high weight open triads for a wide range of success measures in the history of recorded jazz. Innovative teams face the paradox of relying on experience to generate novelty. We argue that forbidden triads, as conjunctures of dyadic experience, are the locations where successful novel combinations can be recognized and realized. Prior scholarship has sidelined such network structural diversity with strong ties, and assumed that strong ties are mostly closed, and weak ties connect to diverse structural locations. We use data on all recording sessions of more than a century of jazz to show that forbidden triad is the only consistent predictor of six measures of success that span the dualities of insiders and outsiders, and voice and trace. This network structure is also the only predictor of deep success: coinciding success in all four quadrants. Furthermore, forbidden triads that require effort beyond easy structural availability contribute in addition to voice measures of success. We discuss implications for project teams and organizations where innovation is a key goal.
\end{abstract}

Keywords: innovation, social networks, forbidden triads, structural folds, jazz

As most creative fields shift from individual to teamwork, challenges of innovation in teams becomes a key problem (Vera and Crossan 2005; Wuchty, Jones, and Uzzi 2007). Teams can pool experiences of members, and rely on interpersonal experience built by pairs of members (DiBenigno and Kellogg 2014), and come to a shared understanding about their task. But if the task is innovation, how does novelty spring from pooled experience? Successful innovation in teams is about solving the paradox of relying on experience but avoiding routine (Deken et al. 2016), and teams need to find a way to recognize possible novel combinations, and to realize these in a product. Teams building from prior experience run the risk of groupthink, when collectively structured cognition limits the scope of attention, and precludes novel ideas (Cerulo 2008; Vaughan 2016; Zerubavel 2015). Teams also run the risk of network closure, that further limits the collective cognitive horizon (Romero, Uzzi, and Kleinberg 2019). Closure in teams facilitates trust, and can ease knowledge transfer (Reagans and McEvily 2003), but can lock teams into routine (Uzzi and Spiro 2005). Several studies on the network antecedents of innovation found that structural diversity - the lack of closure - is key in the capacity to generate novel ideas (Ahuja 2000; Obstfeld 2005).

\footnotetext{
${ }^{1}$ Research for this article was supported by the National Science Foundation (SES-1123807) and Central European University. We thank the assistance of Carl Nordlund in collecting and preparing data. We are grateful for comments and suggestions for David Stark, Brian Uzzi, Matthew Bothner, and workshop participants at University of Oxford. Please direct all correspondence to Balazs Vedres (balazs.vedres@oii.ox.ac.uk).
} 
The main stream of research on network structural diversity shares a fundamental assumption: that strong ties and diversity are mutually exclusive. Weak ties connect to diverse sets of actors opening access to novel information, and strong ties connect to a homogenous set of actors with already known pieces of information. This strength of weak ties hypothesis (Granovetter 1973) was elaborated recently in the diversity-bandwidth tradeoff argument (Aral and Alstyne 2011), that nevertheless excluded strong tie diversity from substantial discussion. The importance of closure in trust and collaboration is a fundamental insight in social networks (Burt 2005). In network analytic terms, open triads of weak ties provide access to diverse novel pieces of information, and close triads of strong ties are trusted context for realizing a novel product.

We argue that, while as a main tendency the strength of weak ties hypothesis holds, strong ties are sometimes open - these are the forbidden triads in Granovetter's terms (Granovetter 1973) - and that these forbidden triads contribute to creative success. Generating a novel idea is an exceptional event, that requires an exceptional social structure. Forbidden triads, as such exceptional conjuncture, enable musicians to recognize and realize a new combination of two dyadically evolved styles. Forbidden triads are at the same time an occasion to discover diverse approaches to collaboration, and they are opportunities to rely on trusted and strong collaborative ties to realize an emerging idea as a product.

The literature on structural folds is one exception that builds from structural diversity around strong ties in communities. Forbidden triads are the elementary building blocks of structural folds. Structural folds are overlapping cohesive communities that contribute to both the recognition of a novel combination, and the realization of that novel idea as a product (De Vaan, Stark, and Vedres 2015). Structural folds are locations of generative tension, where creative success is more likely, but community instability is also increased (Vedres and Stark 2010). A forbidden triad is an elementary structural fold: two pairs of nodes strongly connected, that overlap on a node. The advantage of our approach based on forbidden triads is that triads are easier to identify, and they can be also found in networks without overlapping communities.

Forbidden triads had not been operationalized before ${ }^{2}$. We defined two measures: the density and the depth of forbidden triads, to characterize strong ties structural diversity in a group. The density of forbidden triads corresponds to the amount of innovative possibilities: opportunities to recombine collaborative practices. The average depth of forbidden triads corresponds to the profoundness of innovative opportunities: the length of collaborative histories, hitherto separate, that now can come to a generative contact. The two measures solve the aggregation problem - aggregating triads to the level of the team - in two different ways.

We see the forbidden triad as a robust structure: an organizational form that enables a team to succeed along diverse dimensions. Whereas cohesion, smooth and efficient collaboration might help efficiency, it does not serve innovative goals well (Obstfeld 2005). Other structures, like diverse weak ties might help brainstorm up diverse ideas, but they might not help realizing them (Burt et al. 2004). To test the robust, multifaceted potential in forbidden triads, we develop the notion of deep success - success that spans the dimensions of insider

\footnotetext{
${ }^{2}$ There were publications that claim to operationalize forbidden triads, but mistake then for any open triad (Yang, Dong, and Chawla 2014). Works on Simmelian brokerage and structural folds operationalize structures rich in forbidden triads, but make no reference to triadic operationalization (Krackhardt and Kilduff 2002; Vedres and Stark 2010).
} 
versus outsider origin, and behavioral trace versus explicit judgment. We show that forbidden triads are the only predictors of all four categories of success: insider behavioral traces (the decision to continue the band, as manifested in band survival), outsider behavioral traces (demand for the album produced from the session), insider judgment (award from experts), and outsider judgment (poll results from magazine readers).

Our case is jazz: a uniquely innovative field where producers succeed by novel sounds (Askin and Mauskapf 2017), that offers many lessons to organizations (Barrett 2012; Berliner 1994; Doffman 2011; Phillips 2013) ${ }^{3}$. We use data on 175064 jazz recording sessions - the complete population - spanning the entire history of recorded jazz, using the Tom Lord discographic database. Our dataset contains information on close to two hundred thousand jazz musicians, as they collaborate in sessions, and leave a trace of a weighted collaboration network. We found that the sessions they participated in were more successful by six diverse measures if their collaboration network contained a higher proportion of forbidden triads. Forbidden triads density was the only consistent predictor of success in all six dimensions, and the only significant predictor of deep success. As a comparison, diversity in instrument skills was not a consistent predictor of success, and was a negative predictor of deep success, underscoring the importance of considering diversity as structural, rather than compositional. Weak ties structural diversity was not a consistent predictor of success, and cohesion was a negative predictor.

Beyond investigating the impact of forbidden triads on success, we are also deploying computational methods to separate structural availability and agency. It is difficult to directly access evidence on organizing efforts of teams (as opposed to lucky accidents), but a counterfactual null hypothesis can be generated for each recording session by generating a population of objectively possible sessions, that stay within the broad constraints of musicians and records. We assess the structural availability of forbidden triads by a computational approach, where we simulate counterfactual random jazz worlds that were objectively possible. We found evidence that effort to recruit musicians with forbidden triads when such structures were not easily available had an added contribution to success measures capturing voice: effort to overcome lack of easy availability to include musicians with strong and diverse ties were rewarded when audiences were explicitly naming outstanding performance.

\section{FORBIDDEN TRIADS AND STRUCTURAL DIVERSITY}

Research on team performance demonstrated the benefits of experience (Delmar and Shane 2006; Kor 2003; Vera and Crossan 2005), and the rich account of Robert Faulkner and Howard Becker - both sociologists and active jazz musicians - shows how experience accumulates with performance (Faulkner and Becker 2009). Musicians build a repertoire of standards over their careers, mastering flexibility to play their parts in a wide range of styles. As an accomplished musician puts it:

\footnotetext{
${ }^{3}$ A piece of evidence for the innovative nature of the jazz field is the constant experimentation with diverse instrumentations: we encountered 11,940 unique instruments (after considerable effort to clean and collapse instrument entries). As a comparison, the largest collection of musical instruments, the MIMO project (Musical Instrument Museums Online; mimo-international.com) lists a total of 1140 different kinds of instruments - an order of magnitude less. From car parts to pots and digital noises, jazz musicians go far beyond conventions.
} 
"...the only reason we are able to do it is because we all have enough experience under our belts playing a lot of different kinds of things as sidemen, and we're bringing, without even thinking about it, we are bringing all that information to the bandstand..." (Dockery 2013:801)

It is much less clear how novel and outstanding artistic achievements can stem from past experience. Miles Davis was a bandleader who strived to channel the experience of musicians towards new expressions (Walser 1993), by removing them from their comfort zones:

"See, if you put a musician in a place where he has to do something different from what he does all the time, $[\ldots]$ he'll be freer, will expect things differently, will anticipate and know something different is coming down. I've always told the musicians in my band to play what they know and then play above that. Because then anything can happen, and that's where great art and music happens." (Davis and Troupe 1989:220)

How should we understand that place, where a musician "has to do something different from what he does all the time?" How can a musician be freed to expect things differently, without disconnecting from experience that musicians rely on without even thinking about it? We argue that the dislocation Miles Davis was after is relational. Musicians survive by cultivating their network ties (Dowd and Pinheiro 2013), and Paul Berliner's book on jazz improvisation emphasizes the interpersonal nature of core jazz skills (Berliner 1994).

Musical experience evolves in collaborative ties, and as musicians meet repeatedly on the stage and in the studio, they add to the strength of the tie between them. It is then the rearrangement of these ties that a leader of band, like Miles Davis can compose unexpected constellations of experience.

If musical experience in jazz evolves in dyads, relational dislocations can be captured at the triadic level (Balachandran and Hernandez 2018). To illustrate how Miles Davis's band arranged dyadic experience for innovation, we consider the most successful session of Miles Davis - and in fact the top achievement in the history of jazz, the session on March 2, 1959 that was released on the album "Kind of Blue." Miles brought on board a new piano player, Wynton Kelly. Even though Kelly played only one tune on the album, "Freddie Freeloader", Miles acknowledged his special contribution to the freshness of the music: "Wynton's the light for a cigarette. He lights the fire and he keeps it going." 4 But Kelly was not a novice, and he was not a newcomer to the musicians in the session. Considering the number of prior co-plays as a proxy for dyadic experience, we see that Kelly recorded with Chambers and Cobb more than ten times, but never with Miles. Miles recorded several times with Chambers and Cobb, so the triads of Miles-Chambers-Kelly, and Miles-Cobb-Kelly combines long but distinct dyadic experiences.

Forbidden triads measure structural diversity with strong ties. Research on structural diversity thus far have either neglected the significance of strong ties, or have seen them as a hindrance. The concept of structural diversity refers to the lack of local connectedness of alters for a given ego in a network. Following Mark Granovetter's discovery of the strength of weak ties for structural diversity, it was repeatedly demonstrated that strong ties are more

\footnotetext{
4 Liner notes by Nat Hentoff from Wynton Kelly’s 1960 album "Kelly At Midnight" (http://jazzprofiles.blogspot.com/2011/06/wynton-kelly-1931-1971-pure-spirit.html).
} 
likely organized into closed triads than weak ties, hence early research on structural diversity was focused on weak and open triads. In the original formulation of structural holes by Ronald Burt, the strength of ties was seen as irrelevant for structural diversity: "Whether a relationship is strong or weak, it generates information benefits when it is a bridge over a structural hole." (Burt 1995:28). The formula of structural constraint proposed by Burt in the same book penalizes egos with mixed tie weights, but is invariant to tie weights as long as they are equal.

In Granovetter's original formulation, open but strong triads were seen as exceptions, and were thus labelled forbidden triads. In his seminar article on the strength of weak ties, Granovetter cites sociometric evidence from the sixties and seventies that strong ties tend to be closed. As his focus was on weak bridging ties, the evidence cited was seen to mean that the strong and open forbidden triad do not occur, as "processes of cognitive balance tended to eliminate it" (Granovetter 1973:1364). In fact, in much of the literature on structural diversity, the high weight of ties and the presence of closed triads are seen as an obstacle, a hindrance to brokerage possibilities, demonstrating the negative consequences of overlapping closed triads or dense networks around contacts (Burt 2015; Krackhardt 1999; Krackhardt and Kilduff 2002; Reagans and Zuckerman 2008). A recent re-formulation of the strength of weak ties thesis evaluates conditions under which strong ties might be more beneficial for obtaining diverse information than weak ties (Aral and Alstyne 2011). However, even this article omits to model strong tie structural diversity, as an unlikely network structure, that nevertheless promises the most novelty. In some sense, we are exactly after the cognitive imbalance that Granovetter cites, but we re-frame it as a potential creative force.

A forbidden triad is of interest for a relational understanding of innovation, as a forbidden triad is a conjuncture of two dyadic histories. Following Charles Tilly, we believe that it is relations that store history, and social dynamics emerges from relational conjunctures (Tilly 2000). Population geneticist have long recognized that evolution in separate subpopulations results in a richer set of solutions to environmental challenges, that can be later re-combined (Wright 1932). Recent experimental studies of cultural evolution have shown that a diversity of separate paths leads to higher level of innovation in comparison to a completely cohesive community (Fang et al 2010; Derex and Boyd 2016; Barkoczi and Galesic 2016; Creanza et al 2017). In organizational settings, multiple project team memberships were shown to increase learning (O'leary, Mortensen, and Woolley 2011). According to these studies, communities with longer separate histories of exploration had better chances to generate distinctive cultural combinations by avoiding early lock-ins into consensus.

The advantage of using forbidden triads over general measures of structural fragmentation (like disconnected components, or modularity) is that forbidden triads represent the moment when two separate cultural histories come to a conjuncture, when a novel cultural product can be expected to arise. On Figure 1 you can follow the evolution of two dyadic collaborations, one between musicians Paul Chambers and Miles Davis, and one between Paul Chambers and Wynton Kelly. As a pair of musicians play repeatedly, they elaborate a joint style, and develop a distinctive routine of co-improvisation. When we arrive to the focal session, musician $\mathrm{A}$ is in a position to both recognize a novel combination, and facilitate the way the combination can become a new musical expression. The focal session when a forbidden triad is observed is the moment when exploration can be exploited. 


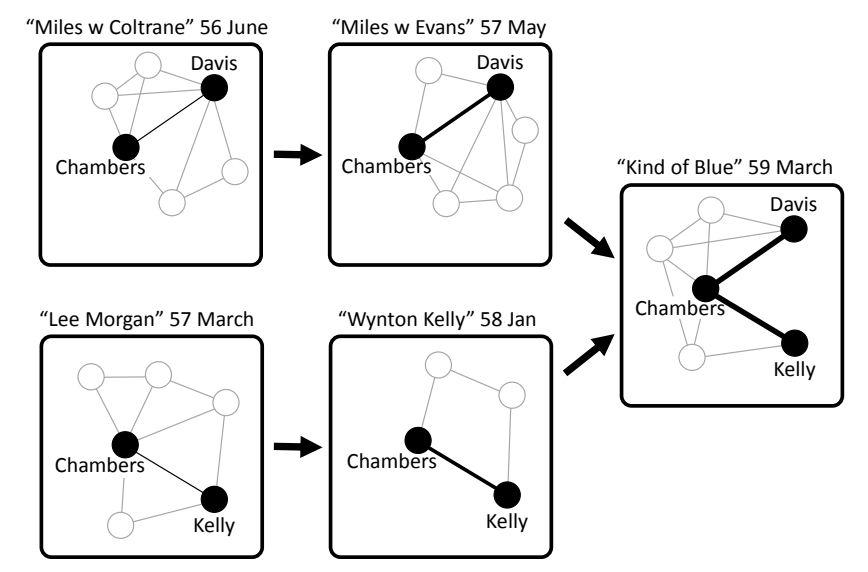

Figure 1: Forbidden triad as conjuncture of dyadic collaborations. White nodes are simplified illustrations of structural context in actual recording sessions. Box titles show actual session labels from the database. Sessions on the top show repeated co-plays of Miles Davis and Paul Chambers, while sessions on the bottom show repeated co-plays of Paul Chambers and Wynton Kelly.

\section{FORBIDDEN TRIADS AS STRUCTURAL FOLDS}

We build on research on structural folds, as a related concept of strong ties structural diversity. Vedres and Stark argued for a crucial difference between structural folds and structural holes, namely that the agency at the overlap of communities matters less than the successful mobilization of the non-intersecting unique parts of overlapping communities (O'leary, Mortensen, and Woolley 2011). The mechanism behind structural folds is generative tension, rather than information and control benefits in brokerage: folds provoke the generation of novelty, as overlapping communities build a product out of their diverse experiences (De Vaan et al. 2015). The difference between structural holes and structural folds arguments are rooted in a difference of theoretical perspective between a formalist and a relational understanding of network processes (Erikson 2016). In a brokerage framework network is imagined as a circuit where durable pieces of information flow freely. In contrast, we think of network ties as locations of accumulating knowledge, and larger network structures where interpersonal histories meet.

We argue that forbidden triads to overcome the operational difficulties of identifying overlapping communities, and provide an easier and unambiguous way to measure the structural folds idea (Vedres 2017). Prior work on fold networks used the number of community memberships of a given node (Vedres and Stark 2010), or the number of subgroup overlaps within a larger collective (De Vaan et al. 2015). Community detection is a complex challenge, with a wide range of algorithms (Granell et al. 2015; Xie, Kelley, and Szymanski 2013). A triadic approach overcomes these challenges, as triad types can be identified unambiguously in any connected and weighted network with more than three nodes. One can think of a forbidden triad is an elementary fold structure, where two communities each with two nodes overlap.

A jazz band beyond a trio has multiple triads, and the question is how we aggregate from the triadic level to the team level. This article uses two measures of forbidden triads: the density of forbidden triads, and the depth of forbidden triads. These two measures correspond to two 
distinct ways in which triads translate to innovativeness in the whole team. First, we use the relative number of forbidden triads compared to all connected triads. With this measure we assume a mechanism where distinct opportunities of combining dyadic experiences are additive: more forbidden triads will result in higher success. Second, we develop a measure that captures the average depth of forbidden triads. With this measure we assume a mechanism where the depth of dyadic experiences that are combined in a forbidden triad is what matters for success. The longer the experience in the two dyads that are meeting in a conjuncture, the higher the success in the team, regardless of the frequency of forbidden triads in the team. In sum, we distinguish the number of opportunities and the depth of opportunities.

\section{DEEP SUCCESS}

If forbidden triads are robust structures that make musicians more innovative in a deeper, multifunctional sense, the music they record should be successful along diverse success measures. Success in art is often measured by just one dimension, like prestige (Fraiberger et al 2018), number of recordings (Philips 2011; Vedres 2017), or chart position (Askin and Mauskapf 2017). We develop the concept of deep success: success that is diverse in both the publics and the generating mechanisms.

Considering publics, success in art is of a dual nature: one can work towards recognition in the eyes of insiders, or strive to achieve financial success by pleasing mass audiences (Bourdieu 1996). The sociology of art have long recognized differences of sophistication in tastes (Hume 2015), and the diversity of roles in art worlds (Becker, Howard 1982), ranging from protagonists on the inside to audience on the outside. The case of smooth jazz illustrates this point: performers in this sub-genre achieved popular and financial success, but were derided by critics as palatable, diluted, anodyne, or sellout (West 2008). Jazz scholars would dismiss this genre as background music, a vehicle to access a wider body of listeners who would never listen to jazz proper (Giddins and DeVeaux 2009).

The duality of insiders and outsiders is maintained because insiders have different stakes and motivations than outsiders: in general, insiders are invested in a role structure, and thus attributing success to others impacts their standing as well (Bourdieu and Johnson 1993; Cattani, Ferriani, and Allison 2014). The by-product of art fields is a status system (Podolny 2008; White 2002), with critics playing a crucial role (White and White 1993).

Beyond the distinction of insiders and outsiders, we need to take another duality into account about the mechanism through which success is conferred: the duality of voice and trace. Art is an arena where opinions about quality, style, worth, and the nature of jazz itself are voiced and debated (Emirbayer and Sheller 1999). Awards, critical acclaim, or polls are forms of success by voice. But success in art can also be accumulated from traces that actions of others leave behind, not with the intention of conferring success on an artist: declarative, and nondeclarative aspects of consuming culture mean two paths to success for producers (Lizardo 2017). Audiences typically vote with their feet and wallets, and the aggregated traces of their decisions become a measure of success for the artist.

Works on the duality of art tend to conflate the insider-outsider distinction with the voicetrace distinction: insiders have voice, outsiders leave traces. Following Jean-Louis Fabiani 
(Fabiani 2003), we take into account the voice of outsiders, and the traces of insiders as well, in a fourfold table.

A mechanism of success can operate in each cell of the fourfold table, to help success in the eyes of insiders, or outsiders, or aid success by voice or by trace. A strong mechanism of success would contribute across both dualities, to achieve deep success.

\section{DATA AND METHODS}

Our data on jazz sessions was collected from the Tom Lord Discography (Lord 2010), arguably the most comprehensive data source on jazz (Charry 2005). The Tom Lord Discography is a database of recording sessions, offering data on the date of a session, the tracks recorded, the musicians present, the instruments musicians played, and the catalog numbers of recordings that contain material from the session. We used data from the very first sessions in 1896 to 2010. Our primary data table is a tripartite graph of sessions, musicians, and instruments, while we also use a session table with record catalog numbers, and date. The resulting dataset contains entries on 175064 recording sessions, 42929 band leaders (or band names), 187784 musicians, playing 11940 different instruments. Moving from the tripartite graph to a one-mode projection, the weighted collaborative network among musicians for a given session was generated by summing the prior co-plays for each musician dyads. To ensure strict temporal ordering, only sessions from year t-1 backwards were included, if the focal session took place in year $t$.

Measuring jazz collaborations as a one-mode projection, capturing the total number of coplays did mean losing information from the original multimode data. We nevertheless think this loss of information is valid (we aim to capture the extent of dyadic experience), and provides sufficient structural variation in the resulting weighted graphs. Session sizes tend to be small, with a median of 6 , and a lowest quartile of 3 , and a musician on average played 6.94 sessions over the career. About two thirds of the graphs are fully connected (67.4\%), where all pairs of musicians have played together at least once, leaving one third of the sessions with structural diversity.

\section{MEASURING STRONG TIE STRUCTURAL DIVERSITY}

The concept of forbidden triads from Mark Granovetter's seminal article (Granovetter 1973) is clear - an open triad with strong ties is a sufficient definition. While there were several advances to formalize Granovetter's original argument (Fararo 1983; Pattison and Robins 2002; Tutić and Wiese 2015; Yang, Dong, and Chawla 2014), there is no empirical measure that operationalizes the forbidden triad concept. Since the argument of structural folds is about team level processes, we define measures of forbidden triads at the team graph level. We propose two measures: the density of forbidden triads $F_{\text {dens }}$, and measure for the depth of forbidden triads $\mathrm{F}_{\mathrm{depth}}$. To define connected triad types including the forbidden triad, we use two quantities: minimal triplet legs weight and weakest edge connectedness. Triplet legs are the two stronger edges in the connected triad, $w_{(3)}$ and $w_{(2)}$, the third (that is, the strongest) and the second strongest edge weights in ascending order of triad edge weights. (The subscripted parenthesized numbers indicate the ascending order statistic.) Minimal triplet 
legs weight is $w_{(2)}$, the second weight in ascending order, that captures the strength of the triad edges, independently of closure.

In a weak open triad $\tau_{\Omega \mathrm{w}}$, the weakest edge $w_{(1)}=0$ (hence the triad is open), and the other two connected edges are weak ties. In other words, $w_{(2)}<t$, that is, in an open triad the minimal legs weight is smaller than threshold $t$, if this threshold separates weak ties from strong ties. A closed triad $\tau_{\Delta}$ has three connected edges regardless of tie weight. And finally, a forbidden triad $\tau_{\mathrm{f}}$ is open in the sense that $w_{(1)}=0$, but the minimal legs weight $w_{(2)} \geq t$, hence the two connected edges in the forbidden triad are strong ties. So the definition of forbidden triad is:

$$
\tau_{\mathrm{f}}= \begin{cases}1 & \text { if } w_{(2)} \geq t \quad \& \quad w_{(1)}=0 \\ 0 & \text { otherwise }\end{cases}
$$

These definitions satisfy the requirement that $\tau=\tau_{\Omega \mathrm{w}} \cup \tau_{\Delta} \cup \tau_{\mathrm{f}}$. The three triad types are summarized in Table 1.

\begin{tabular}{ccc}
\hline \hline & $\begin{array}{c}\text { Minimal legs } \\
\text { weight }\end{array}$ & $\begin{array}{c}\text { Minimal edge } \\
\text { weight }\end{array}$ \\
\hline$\tau_{\Omega \mathrm{w}}$ & $w_{(2)}<t$ & $w_{(1)}=0$ \\
$\tau_{\Delta}$ & $w_{(2)}>0$ & $w_{(1)}>0$ \\
$\tau_{\mathrm{f}}$ & $w_{(2)} \geq t$ & $w_{(1)}=0$ \\
\hline \hline
\end{tabular}

Table 1: Definition of triad types

We calculate the density of forbidden triads as the proportion of forbidden triads of all connected triads:

$$
\mathrm{F}_{\mathrm{dens}}=\frac{\sum \tau_{\mathrm{f}}}{\sum \tau}
$$

The assumption behind this measure is that what matters for creative success is the relative frequency of forbidden triads, and not the intensity of tie weights in these triads. The more forbidden triads a jazz session has, the more choices musicians have to pursue interesting combinations of dyadic styles. This measure depends only on the $t$ threshold for a strong tie. (In our analysis we will test the robustness of our findings to varying $t$.)

Similarly, we calculate the density of open triads as the proportion of all connected triads and the density of closed triads as the proportion of all connected triads. By definition the propensity of forbidden triads, open triads and close triads add up to one in any given network.

We also develop a second measure of strong tie structural diversity, forbidden triads depth. This coefficient measures the sum of geometric means of relative edge weights in open triads, normalized by the number of open triads. Here we consider open triads $\tau_{\Omega}$ regardless of the tie weight threshold, such that $\tau_{\Omega}=\tau_{\Omega \mathrm{w}} \cup \tau_{\mathrm{f}}$. This measure follows the same considerations that underlie the development of weighted clustering coefficients, where the geometric mean 
of relative edge weights is used, as it is more robust to outlying weight values (Onnela et al. 2005; Opsahl and Panzarasa 2009; Saramäki et al. 2007).

First, relative edge weights are calculated by dividing each weight by the maximum weight, $\widehat{w}_{i j}=w_{i j} / \max (w)$. Then we calculate the geometric mean of weights in open triads, $\widehat{w}_{\Omega}=\left(\widehat{w}_{(2)} \widehat{w}_{(3)}\right)^{1 / 2}$, for the two non-zero weight edges. The coefficient is then calculated by the following formula:

$$
\mathrm{F}_{\text {depth }}=\left\{\begin{array}{l}
\frac{\sum_{\tau_{\Omega}} \widehat{w}_{\Omega}}{\sum \tau_{\Omega}} \text { if } \mathrm{F}_{\mathrm{dens}}>0 \\
0 \text { otherwise. }
\end{array}\right.
$$

This coefficient captures the weight of forbidden triads independently of the proportion of such triads. $F_{\text {depth }}$ is set to zero for full graphs where $\sum \tau \Omega=0$, and $F_{\text {depth }}$ is not applicable for graphs without any connected triads (thus sessions with empty graphs are omitted). The measure ranges from zero, with no weight in open triads, to one, with all open triads having ties that have the maximal tie weight in the session.

The assumption behind this measure is that it is not the number of forbidden triads that counts, but the "depth" of them: the larger the weights in forbidden triads, the more mature and elaborate are the artistic expressions developed in the high-weight dyads. Juxtaposing these more elaborate dyadic experiences can then lead to more striking, novel combinations.

This measure is also normalized by the highest tie weight in the session, making the depth of the experiences relative. The assumption behind this is that combining diverse experiences need to compete with well-rehearsed conventions in closed triads. A depth coefficient of 0.5 suggests that there is at least one closed triad with a tie weight that is twice as high as the weight in an open triad, regardless of the actual number of sessions that this means.

Table 2 with the weighted adjacency matrix and Figure 2 with the weighted network graph illustrates these measures with the March 2, 1959 session of Miles Davis where three tracks of the "Kind of Blue" album were recorded.

\begin{tabular}{lrrrrrr}
\hline & 1 & 2 & 3 & 4 & 5 & 6 \\
\hline 1 Paul Chambers (bass) & & 35 & 12 & 8 & 22 & 13 \\
2 John Coltrane (tenor sax) & 1.00 & & 1 & 7 & 16 & 5 \\
3 Wynton Kelly (piano) & .34 & .03 & & 11 & 0 & 1 \\
4 Jimmy Cobb (drums) & .23 & .20 & .31 & & 6 & 10 \\
5 Miles Davis (trumpet) & .63 & .46 & .00 & .17 & & 8 \\
6 Cannonball Adderley (alto sax) & .37 & .14 & .03 & .29 & .23 & \\
\hline
\end{tabular}

Table 2: Matrix of the number (upper triangle) and relative number (lower triangle) of prior co-recordings of the musicians in the "Kind of Blue" session of Miles Davis (March 2, 1959). 


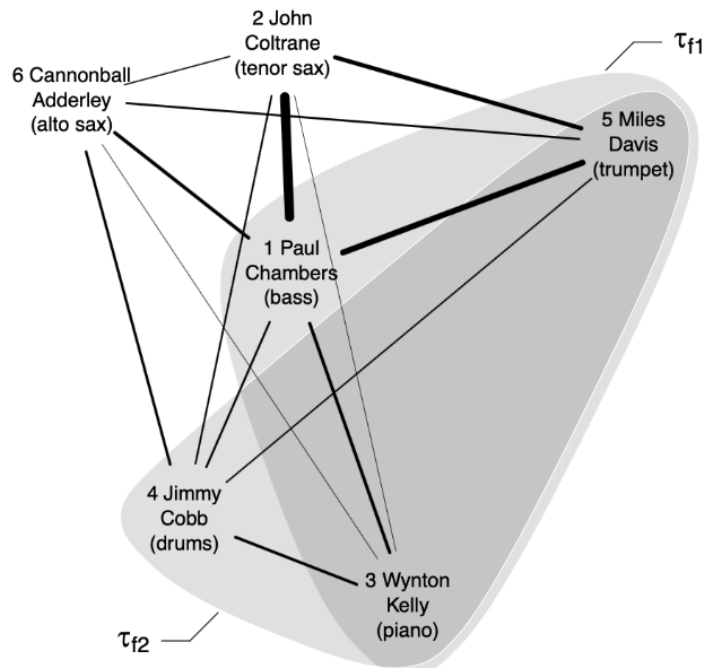

Figure 2: Graph of prior co-recordings in the example session of "Kind of Blue" (March 2, 1959). Forbidden triads with $\mathrm{t}=2, \tau_{\mathrm{f} 1}$ and $\tau_{\mathrm{f} 2}$, are marked by shaded areas.

The album resulting from this session, "Kind of Blue" is the top achievement in the history of jazz: the most influential, most mentioned, and most re-issued jazz. As for any session in our dataset, we show the number of prior collaborations up to the end of the preceding year, 1958 in this case. For example, as the weighted matrix shows on Table X, Paul Chambers played in 22 sessions with Miles Davis. There is only one missing edge in the collaborations graph Miles Davis has never recorded in the studio with Wynton Kelly before - but this one missing edge generates two open triads and to forbidden triads, and the rest, 16 triads are closed. The forbidden triads density, $\mathrm{F}_{\text {dens }}$ is 0.09 , and the forbidden triads depth, $\mathrm{F}_{\text {depth }}$ is 0.22 , meaning that the mean tie weight of forbidden triads was $22 \%$ of the highest tie weight. As comparison, the weighted clustering coefficient (the mean tie weight of closed triads) is 0.21 , so the weights in open triads were on average stronger than the weights in closed triads.

\section{DEPENDENT VARIABLES OF SUCCESS}

We used altogether six dependent variables, to have at least one in each of the quadrants in our table that charts the range of success. We distinguish insider and outsider publics, and two mechanisms of conferrence: voice and trace. Table 3 shows the typology of variables.

\begin{tabular}{llll}
\hline & \multicolumn{2}{c}{ public } \\
& \multicolumn{1}{c}{ insider } & \multicolumn{1}{c}{ outsider } \\
\hline conferrence & voice & $\begin{array}{l}\text { 1. NEA Award } \\
\text { 2. Critics' Poll }\end{array}$ & 3. Readers' Poll \\
& & trace & 4. Book mention \\
& & 5. Survival & 6. Releases \\
\hline
\end{tabular}

Table 3: Typology of dependent variables of success in jazz.

Two variables measure the explicit evaluation of success by insiders. The first is NEA award. Every year since 1982, the National Endowment for the Arts (NEA) honors a small number 
of jazz musicians with this lifetime achievement award. NEA is an agency of the U.S. government but the wider public nominates the jazz artists for consideration of this award. The NEA Jazz Masters Fellowship goes to living musicians well embedded in their field and is aimed at crowning their already successful career. We coded this measure as 1 for all sessions in the career of a band preceding the year of the award and we excluded all sessions of awarded bands in and after the year of the award.

The second indicator of success evaluated by insiders is the Critics' Poll. One of the leading and longest running industry periodicals, the DownBeat magazine, administers this recognition since 1961. They survey jazz critics in several categories on a yearly basis to capture industry sentiment. The most prestigious category of the Poll is the Hall of Fame, which aims to honor the most outstanding artists in the field. We coded this measure as 1 for all sessions in the career of a band preceding the year of the award and we excluded all sessions of awarded bands in and after the year of the award.

Although industry insiders do have a prominent voice, they are not the only ones who express their opinion about jazz music. We use one variable to indicate explicit judgment calls by outsiders: results from Readers' Poll surveys. Besides polling industry insiders, DownBeat Magazine also surveys its readers on a yearly basis to pick Hall of Fame members. In fact, this award dates back earlier than the Critics' Poll, to 1952. There is little burden of participating in the survey, jazz enthusiasts do not need to be subscribers of the magazine. We coded this measure as 1 for all sessions in the career of a band preceding the year of the award and we excluded all sessions of awarded bands in and after the year of the award.

Besides explicit judgment, social science can follow the behavioral traces of industry insiders and outsiders to proxy the perceived success of jazz music. We measured the behavioral traces of industry insiders in two ways. Book mentions indicate the decision by the editors and authors to reference sessions in canonical jazz textbooks. When a jazz session was discussed at least once in any of the books mentioned in our Appendix A, we recorded this in a dummy variable. We assumed that these mentions aim to situate the sessions in the wider history of jazz and as such are acknowledging accomplishment.

Survival is probably the most basic behavioral trace of performance as survival indicates the willingness of team members to continue their career. We measured the end of survival indirectly. We used the full range of event histories of bands that had at least two recorded sessions. Sessions that were the last in a band's career were coded as 1 . We also calculated a clock variable and stored the number of days from the previous recorded session in a given band's career trajectory. We used the exact date of the recordings to calculate this measure. In cases where sessions were recorded on the same day, we randomized the order of those sessions. As sessions with day ties comprise $27 \%$ of the sample, we repeated this process several times and checked the consistency of our results.

Finally, we used a variable to indicate the behavioral traces of outsiders. Releases captured the behavior of audiences as it manifests in purchasing albums. As releases accumulate over time, we used an aggregate version and calculated the number of releases per decade. For its skewness, we used the logarithmically transformed version of this variable.

To capture coinciding success along the four categories we have defined, we coded the variable Deep success the following way: 


$$
\text { Deep success }= \begin{cases}1 & \text { if }\left(s_{1} \cup s_{2}\right) \cap s_{3} \cap\left(s_{4} \cup s_{5}\right) \cap s_{6}=1 \\ 0 & \text { otherwise. }\end{cases}
$$

where $s_{1}$ is NEA award, $s_{2}$ is Critics' Poll, $s_{3}$ is Readers' Poll, $s_{4}$ is Book mentions, $s_{5}$ is $\mathrm{s}$ recoded version of Survival, and $s_{6}$ is a recoded version of Releases. In order to have all these variables measured on the binary scale, we measure survival with a dummy indicator differentiating between the the last $(=0)$, as opposed to the not last $(=1)$. To measure releases with a dummy variable, we differentiate between the session belonging to the top 5\% of sessions in terms of the number of releases $(=1)$, and the bottom $95 \%(=0)$. The resulting Deep success variable captures sessions that were successful in all four categories of insider voice, outsider voice, insider trace, and outsider trace.

\section{CONTROLS}

There are competing mechanisms that can account for different dimensions of success in creative industries. We accounted for these possibilities by using a set of control variables.

First, network size is a factor to consider. A growing network allows for more structural possibility to form triads which could render the relationship between forbidden triads and success spurious. To check the robustness of our focal relationship against this alternative explanation, our models controlled for the number of musicians per session.

Second, past performance imbues musicians with experience. Over time, musicians develop routines and expertise, making them both more prone to have more forbidden triads in their network and to achieve creative success. We measured past performance in a couple of ways. The variable session tenure counted the total number of times the band previously played together assessing the alternative explanation that inherent expertise predicts creative success regardless of network structure. The variable median co-plays indicated dyad-level cumulated expertise. We used the cumulative frequency of each previous musician pair co to create a session-level measure by calculating the median of all pair-wise histories. This measure considered the alternative explanation that seasoned dyadic relationships constitute the hotbeds of creative success.

Furthermore, we defined release history an indicator variable that took the value of 1 if past sessions had been released more than one time. Music publishers use past release success as an indicator to gauge expected future success of bands. To make sure that the link between network structure on success does not come from this source of spuriousness, we used this measure in the model as control.

Finally, the qualitative distinctiveness of bands compared to others in the field contribute to the reception of their music. The variable distinctiveness of instrument combinations measured the extent to which the set of instruments create a unique combination. Uniqueness measured the average cosine distance of the instrument combination vector of the session (in the space of the top 200 most frequent instruments) to all other sessions over the preceding five years (y-1 to y-5). By adding this variable to our models, we accounted for the alternative explanation that having several forbidden triads is just a by-product of diverse instrumentation, not the driving force of creative success per se. 


\section{SAMPLES AND METHODS}

Although we had information on the entire history of recoded jazz, features of the empirical context and methodological considerations required slightly different samples for each of the six dependent variables of interest. To estimate winning the NEA, Critics' Poll, Readers' poll awards and book mentions, we fit maximum likelihood models with a logistic function to predict whether sessions of a band were mentioned or recognized. We decided to model the presence of any book mentions for a session, rather than the number of mentions, as there were very few sessions (199) mentioned multiple times. We attempted to use negative binomial and zero inflated negative binomial models, with and without fixed effects for band, but neither of these models showed significant coefficients for our network structure variables. Alternative specifications for all of our models are presented in the supplement.

While bands receive awards and poll nominations not sessions, we decided to use session level models as - according to the coding scheme described previously - our mechanisms are at the session level. We also ran models at the band level, aggregating independent variables by taking the means, and using rare events (penalized likelihood) logistic regression, with correction for bias resulting from rare events, that is in this case, exceedingly small number of observations with a success outcome (King and Zeng 2001).

The sample sizes of the maximum likelihood models differed across specifications as we excluded careers that ended before the year the awards started: 1982, 1961, and 1952 respectively. In the NEA, Critics' Poll, Readers' poll models, we ended our dataset in 2000, leaving a ten-year window for the different dimensions of success to manifest. For the book mention models, we only used sessions between 1940 and 1970 to focus on the heyday of jazz and its later reception. We restricted all these models to sessions that have an appropriately long history meaning at least four sessions and at least three musicians so our network measures could be calculated.

We estimate semi-parametric piece-wise exponential models with a continuous rate of band survival. To make the baseline relationship between the rate of survival and band career length flexible, we include time pieces in our models for career stages (the cut-points divide up survival time to early, mid, and late careers where we expect the baseline hazard to be fairly constant). We only used the full range of event histories of bands that had at least two recorded sessions. The running variable was the time elapsed between sessions and we calculated it from the exact date of the recording until the last session or right censoring event (Mezias and Mezias, 2000). As our survival models contain band session histories in their entirety, we included a dummy variable, missing, to indicate sessions in which the network was not developed enough for us to calculate structural measures.

Our strategy was the following to model the amount of releases per decade. We fit linear models to predict the logarithmically transformed version of this measure. We use information from the beginning of the recorded session history, the earliest year being 1896 . However, we leave a ten-year window for success to manifest so our dataset ends in 2000. As with other models, we restrict the sample to sessions with sufficient history to calculate network measures. Out of the six dependent variables, the number of releases was the only measure with missing values: $1.5 \%$ of the release variables were missing. As it is customary to not use imputation techniques on missing dependent variables, we had no option but to use listwise deletion on these cases (Allison 2009). Our models for releases include fixed effects for band, to estimate within-band effects, as we can assume unobserved heterogeneity in 
releases at the band level: An album from Miles Davis will be more likely to be re-released, regardless of the network configurations in the session, compared to a relatively unknown jazz band.

\section{RESULTS}

Table 4 shows descriptive statistics of our variables. To chart the distribution of sessions by the prevalence of triad types, we use a ternary plot, as shown on Figure 3. A ternary plot is a multi-dimensional histogram, when there are three variables that add up to a constant. As proportions of three kinds of triads - closed, weak open, and forbidden - add up to unity, it is appropriate to chart our sessions using this plot (Wickham 2009).

\begin{tabular}{lrrrr}
\hline & Mean & SD & Min & Max \\
\hline Forbidden triads density & .069 & .180 & .000 & 1.000 \\
Forbidden triads depth & .127 & .228 & .000 & 1.000 \\
Open triads density & .153 & .279 & .000 & 1.000 \\
Closed triads density & .441 & .433 & .000 & 1.000 \\
N musicians & 7.476 & 6.687 & 1.000 & 113.000 \\
Session tenure & 182.479 & 260.329 & .000 & 5511.000 \\
Median co-plays & 1.336 & 3.973 & .000 & 141.000 \\
Release history & .338 & .473 & .000 & 1.000 \\
Distinctiveness & .655 & .120 & .000 & 1.000 \\
Year & 82.012 & 22.106 & 3.000 & 114.000 \\
NEA Award & .063 & .243 & .000 & 1.000 \\
Critics' Poll & .032 & .175 & .000 & 1.000 \\
Readers' Poll & .040 & .195 & .000 & 1.000 \\
Book mention & .004 & .063 & .000 & 1.000 \\
Band failure & .131 & .338 & .000 & 1.000 \\
Releases & -.208 & .362 & -1.045 & 1.482 \\
\hline
\end{tabular}

Table 4: Descriptive statistics.

If forbidden triads were truly forbidden - absent - we would expect the ternary plot to only show density along the horizontal axis, with sessions that combine closed triads and weal open triads. This is clearly not the case. Certainly, there are many sessions with only one kind of triad (only closed triads in $67.4 \%$ of all sessions, only weak open triads in $11.3 \%$ of sessions, and only forbidden triads in $3.4 \%$ of sessions). But moving away from the three corners of the plot, there are $17.8 \%$ of sessions combining various kinds of triads. About two thirds of these, $11.8 \%$ of all sessions, contain forbidden triads - this is the denser region of the triangle plot towards the lower right side. 


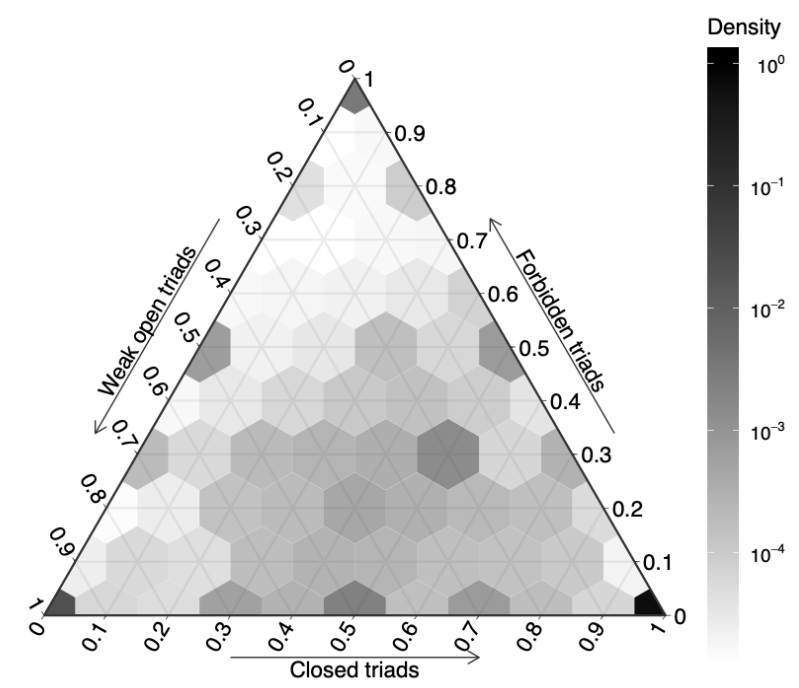

Figure 3: Ternary plot with the relative frequency of sessions according to their triadic composition.

Correlations among independent variables do not raise concern for pairwise multicollinearity (multicollinearity in the variable set was also not of concern; the maximal VIF was 1.29).

Correlations among the dependent variables are low (maximum is .339), which indicates that we indeed captured diverse dimensions of success.

\section{FORBIDDEN TRIADS AND SUCCESS}

For all six dependent variables, we run two models in which we use different measures of forbidden triads: the density and depth of forbidden triads. All models control for alternative mechanisms. Table 5 gives an overview of our results. 


\begin{tabular}{|c|c|c|c|c|c|c|c|c|c|c|c|c|}
\hline & \multicolumn{2}{|c|}{$\begin{array}{l}\text { I. NEA Award } \\
\text { (logit odds ratio) }\end{array}$} & \multicolumn{2}{|c|}{$\begin{array}{l}\text { II. Critics' Poll } \\
\text { (logit odds ratio) }\end{array}$} & \multicolumn{2}{|c|}{$\begin{array}{l}\text { III. Readers' Poll } \\
\text { (logit odds ratio) }\end{array}$} & \multicolumn{2}{|c|}{$\begin{array}{l}\text { IV. Book mention 1940- } \\
\text { 1969, (logit odds ratio) }\end{array}$} & \multicolumn{2}{|c|}{$\begin{array}{c}\text { V. Survival } \\
\text { (hazard ratio) }\end{array}$} & \multicolumn{2}{|c|}{$\begin{array}{l}\text { VI. Releases (per decade, } \\
\text { log; OLS) }\end{array}$} \\
\hline & 1 & 2 & 3 & 4 & 5 & 6 & 7 & 8 & 9 & 10 & 11 & 12 \\
\hline Forbidden triads density & $\begin{array}{l}1.424^{* * *} \\
(.097)\end{array}$ & & $\begin{array}{l}1.387^{* *} \\
(.140)\end{array}$ & & $\begin{array}{l}1.476^{* * *} \\
(.125)\end{array}$ & & $\begin{array}{l}1.761^{* *} \\
(.388)\end{array}$ & & $\begin{array}{l}.854^{* *} \\
(.045)\end{array}$ & & $\begin{array}{l}.018^{* * *} \\
(.005)\end{array}$ & \\
\hline Forbidden triads depth & & $\begin{array}{l}1.558^{* * * *} \\
(.119)\end{array}$ & & $\begin{array}{l}1.378 * * \\
(.156)\end{array}$ & & $\begin{array}{l}1.378^{* *} \\
(.156)\end{array}$ & & $\begin{array}{l}1.600 \dagger \\
(.398)\end{array}$ & & $\begin{array}{l}.821^{* * *} \\
(.044)\end{array}$ & & $\begin{array}{l}.019 * * * \\
(.006)\end{array}$ \\
\hline Constant & $\begin{array}{l}.028^{* * *} \\
(.004)\end{array}$ & $\begin{array}{l}.028^{* * *} \\
(.004)\end{array}$ & $\begin{array}{l}.052^{* * *} \\
(.009)\end{array}$ & $\begin{array}{l}.051^{* * *} \\
(.009)\end{array}$ & $\begin{array}{l}.336 * * * \\
(.056)\end{array}$ & $\begin{array}{l}.051^{* * *} \\
(.009)\end{array}$ & $\begin{array}{l}.000^{* * *} \\
(.000)\end{array}$ & $\begin{array}{l}.000^{* * *} \\
(.000)\end{array}$ & $\begin{array}{l}.218^{* * *} \\
(.001)\end{array}$ & $\begin{array}{l}.219^{* * *} \\
(.019)\end{array}$ & $\begin{array}{l}-.795^{* * * *} \\
(.014)\end{array}$ & $\begin{array}{l}-.795^{* * *} \\
(.014)\end{array}$ \\
\hline Controls included & yes & yes & yes & yes & yes & yes & yes & yes & yes & yes & yes & yes \\
\hline Year trend included & yes & yes & yes & yes & yes & yes & yes & yes & no & no & yes & yes \\
\hline Band time included & no & no & no & no & no & no & no & no & yes & yes & no & no \\
\hline Band fixed effect included & no & no & no & no & no & no & no & no & no & no & yes & yes \\
\hline $\begin{array}{l}N \\
R^{2}\end{array}$ & $\begin{array}{l}72,642 \\
085^{1}\end{array}$ & $\begin{array}{l}72,642 \\
085^{1}\end{array}$ & $\begin{array}{l}72,255 \\
078^{1}\end{array}$ & $\begin{array}{l}72,255 \\
078^{1}\end{array}$ & $\begin{array}{l}72,381 \\
136^{1}\end{array}$ & 72,255 & $\begin{array}{l}22,820 \\
068^{1}\end{array}$ & $\begin{array}{l}22,820 \\
068^{1}\end{array}$ & 97,184 & 97,184 & $\begin{array}{l}71,817 \\
110^{2}\end{array}$ & 71,817 \\
\hline AIC & 34,225 & 34,219 & 19,205 & 19,204 & 23,701 & 19,204 & 3,511 & 3,513 & 49,928 & 49,923 & & \\
\hline $\mathrm{BIC}$ & 34,299 & 34,293 & 19,279 & 19,277 & 23,774 & 19,277 & 3,575 & 3,579 & 50,099 & 50,094 & & \\
\hline
\end{tabular}

Table 5: The effect of forbidden triads on six measures of success. 
Insider voice. We used two measures of indicators of insider voice: receiving an NEA Award (I) and winning the Jazz Critics' Poll (II). Higher proportion and deepening breadth of forbidden triads both raise the odds of receiving the NEA award even after accounting for other mechanisms that contribute to success (models I.1 and I.2). Similarly, both forbidden triad measures are statistically significant antecedents of winning the Jazz Critics' award (II.1 and II.2.). Forbidden triad density and depth thus consistently predict creative success evaluated by industry insiders.

Outsider voice. One measure indicated success based on outsider voice, Readers' Poll results (III). Networks both dense (III.1) and deep (III.2.) in forbidden triads raise the odds of accolade by the public. Thus, recording success evaluated not only by insiders but also by the wider public seems to be strongly related to the structural characteristics of the band that is recording the session.

Insider trace. We used two proxies of innovative performance measured by industry insider's behavior: book mentions (IV) and band survival (V). The odds of being mentioned in a canonical book on jazz rise when the network composed of the career histories of band members is dense in forbidden triads (IV.1). While results are similar in sign, the positive relationship between forbidden triad depth and book mentions cannot be confirmed at the 0.05 level. As for the survival benefits of network composition, our results reveal that survival benefits accrue to networks both with higher density and depth of forbidden triads (V.1 and V.2). In sum, models of insider behavioral traits show that forbidden triads predict innovative performance.

Outsider trace. One measure indicated innovative performance based on traces of the public. Results from linear models predicting the number of releases (VI) replicate a previous finding (Vedres 2017) and show the positive effects of both forbidden triads density (VI.1.) and depth (VI.2.) on release numbers. It thus highlights that innovative performance measured by where the customer's money is going depends on the network setup of the jazz band.

\section{DEEP SUCCESS}

In order to evaluate the magnitude of the effect of network structure on different measures of success, we decided to measure all six of the dependent variables on the same scale, and use standardized values for our independent variables. Since most of our dependent variables are binary, this meant simplifying the dependent variable in our release model and choosing a different model specification for our survival model. Once we set up the six dependent variables in binary form, we repeat running the maximum likelihood models with logistic function reported in the previous session with the difference compared to earlier models that we standardize all independent variables in the models. The advantage of this approach that the coefficients from the different models will become directly comparable across and within models.

In addition to the six dependent variables, we also modeled deep success, coinciding success in each of the four categories we have defined. Since such sessions were exceedingly rare (206 sessions, .016\%), we used a rare events penalized likelihood logit model for this dependent variable.

Besides comparing the coefficients of forbidden triads density and depth, the variables of our previous focus, we also compare the estimates for measures that were advanced by earlier 
research as alternative explanations. Thus, we compare the estimates for the effect of weak open triads, closed triads and the distinctiveness of instruments in a band.

Figure 4 visualizes our findings from these models. We structured the layout of this visualization so we compare coefficients of five independent variables (columns) on our six measures of success (point estimates and confidence intervals). Furthermore, we calculate the composite measure of deep success the following way: we create an indicator variable that only takes the value of 1 if a session achieved success in all the cells in the insider/outsider and voice/trace matrix. If the confidence interval line does not cross the horizontal line at 1 , it means that the effect of that independent variable is statistically significant. If the line is above the horizontal line, it means that the specific network measure is positively associated with that outcome variable.

Results reported in the first column stand out from models reported in 2-5 columns because all the values are positive and statistically significant. Depth positively predicts five out of six distinct measures of success, only readers' poll assessments being insignificant. However, the composite measure of deep success stays statistically insignificant. Overall, we find that forbidden triads consistently predict all measures of success, including deep success.

The consistency of the positive impact of forbidden triads gains further relevance if we compare it with other possible measures of triad combinations. Columns 3 and 4 report these models. Any given session and the career histories of musicians of participating musicians be decomposed to three triad-level measures: the proportion of forbidden or strong open triads, the proportion of weak open triads, and the proportion of closed triads. These three proportional measures add up to 1 . If we compare results in columns 3 and 4 to column 1, we can see that only forbidden triads predict consistently all dimensions of success. Although weak open triads fare well on some measures - such as NEA Awards and survival - they are not the single most important predictors of success. Closed triads, as expected, are negatively associated with most measures of success. Finally, the uniqueness of instrument combination results in column 5 reveal that besides survival, distinctiveness of instrumentation is negatively related to most types of innovative performance. These results underline that it is not the composition of the instruments but the uniqueness of styles contributes to innovative performance.

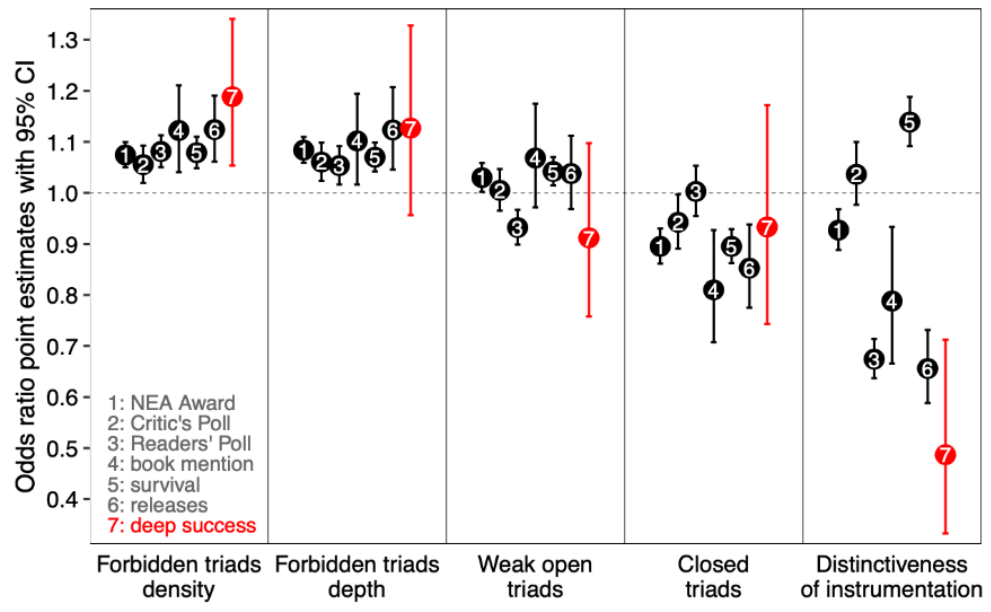

Figure 4: Point estimates (odds ratios) from logit models, with 95\% confidence intervals for standardized independent variables. Estimates are grouped by independent variable (categories on the horizontal axis), and numbered from 1 to 7 by dependent variables. 
Modeling success in a comparable way - with logit models for all dependent variables, and with standardized independent variables - also provides an opportunity to assess specification sensitivity in a comparable way. By estimating models with all combinations of our six control variables (including none at all, or any. number and combination of them -64 models in all), we can evaluate the sensitivity of our forbidden triads density and depth coefficients. We found that for all dependent variables and all specifications the coefficients remained positive and significant, with the exception of three specifications for releases.

\section{SUCCESS AND STRUCTURAL AVAILABILITY}

The previous results do not account for whether the different dimensions of innovative success come to life solely through the opportunity of structure or they require conscious and strategic effort of band members. In this section, we compare our empirical jazz networks to simulated random graphs. We aim to understand whether a network rich in forbidden triads leads to creative success depending on whether forbidden triads are more or less likely to occur in given structures in the first place. In doing so, we separate the effects of the agency of the band and the opportunity structure of networks. Although we will not be able to determine if the agency of the band is an instantiation of innate instinct, cognitive heuristics or rational-instrumental action, nevertheless, we will be able to differentiate this strategicconscious human action from outcomes that are results of the structural possibility.

To estimate expectations for structural availability, we generated 100 random jazz worlds by rewiring the observed tripartite dataset (of sessions, musicians, and instruments). The rewiring was accomplished following the principle of objective possibility: We were reallocating musicians to sessions in a way that could have happened in real life (with, albeit, small probability), and avoided composing sessions that were not possible according to available evidence. In other words, we were generating jazz worlds with synthetic sessions that the recording companies could have recorded. These random jazz worlds are different from the actual one on that musicians selected by our rewiring were not selected according to their networks. They were not likely to have played with each other in the past, and they were not likely to have been "friends of friends" either.

The first principle for rewiring was that the number of musicians in the session needed to be preserved. Second, we were preserving the number of sessions a musician played, within a window of one year. If a trumpet player recorded five times over the year when the session happened, we were allocating that player to five sessions in the rewired jazz world over that one-year period. We were also using 2, 5 and 10 year windows, but the one year window is the closest to the logic of the jazz field, and it is also the strictest in the availability of musicians. Third, we preserved the instrument combination of the session, as the recorded material would have been different without the same instruments. Finally, we were only allocating musicians to a session to fill an instrument slot if they played the instrument over the current and previous year. Musicians often play multiple instruments, and it makes a considerable difference if a musician has played the instrument in question only a decade in the past.

Once we generated the random worlds, we calculated our forbidden triads density and depth variables, and computed a Z-score measuring the distance of the observed and expected statistics. Table 6 highlights our results. The coefficient forbidden triads $=0$ covers cases when there is no structural possibility for forbidden triads to form. The coefficient forbidden 
triads $>0$ and $Z>=2$ entails cases when the structural opportunity is not readily available, and bands are very likely making a conscious effort to recruit musicians with forbidden triads. The coefficients to these two categories can be read as comparisons to an omitted category. This reference category covers cases with forbidden triads $>0$ and $Z<2$, instances when forbidden triads in the observed session are not more likely than in the random jazz world.

The results reveal that band effort matters differently for voice and trace outcomes. Behavioral trace outcomes, such as book mention, survival and releases, are not associated with conscious strategic action. The insignificant coefficients in line 2, columns 7, 9 and 11 represent that it does not matter whether the band makes a unique effort to engineer their network. Extra opportunities do not present themselves as results of additional human effort on top of the possibility embedded in the network structure itself.

For outcomes associated with explicit judgment, such as NEA Award, Critics' Poll and Readers' Poll results, a strong association is apparent with conscious human action. The results in line 2, columns 1,3 , and 5 highlight that compared to chance findings, network constellations that are outcomes of conscious recruitment are richer in forbidden triads that would be expected from structural possibilities alone. These network structures, consequently, act as conduits of innovative success but only on explicit judgment outcomes. These outcomes are judged by audiences, whose identity is also on the line when making these evaluations. 


\begin{tabular}{|c|c|c|c|c|c|c|c|c|c|c|c|c|}
\hline & \multicolumn{2}{|c|}{$\begin{array}{l}\text { I. NEA Award } \\
\text { (logit odds ratio) }\end{array}$} & \multicolumn{2}{|c|}{$\begin{array}{l}\text { II. Critics' Poll } \\
\text { (logit odds ratio) }\end{array}$} & \multicolumn{2}{|c|}{$\begin{array}{l}\text { III. Readers' Poll } \\
\text { (logit odds ratio) }\end{array}$} & \multicolumn{2}{|c|}{$\begin{array}{l}\text { IV. Book mention 1940- } \\
\text { 1969, (logit odds ratio) }\end{array}$} & \multicolumn{2}{|c|}{$\begin{array}{l}\text { V. Survival } \\
\text { (hazard ratio) }\end{array}$} & \multicolumn{2}{|c|}{$\begin{array}{l}\text { VI. Releases (per decade, } \\
\text { log; OLS) }\end{array}$} \\
\hline & 1 & 2 & 3 & 4 & 5 & 6 & 7 & 8 & 9 & 10 & 11 & 12 \\
\hline $\begin{array}{l}\text { Forbidden triads density }>0 \text {, } \\
\text { and } Z \geq 2\end{array}$ & $\begin{array}{l}1.227^{* * *} \\
(.060)\end{array}$ & & $\begin{array}{l}1.272^{* * *} \\
(.091)\end{array}$ & & $\begin{array}{l}1.225^{* * *} \\
(.047)\end{array}$ & & $\begin{array}{l}9.960 \\
(.164)\end{array}$ & & $\begin{array}{l}.939 \\
(.039)\end{array}$ & & $\begin{array}{l}-.004 \\
(.004)\end{array}$ & \\
\hline $\begin{array}{l}\text { Forbidden triads depth }>0 \text {, } \\
\quad \text { and } Z \geq 2\end{array}$ & & $\begin{array}{l}1.138 \\
(.457)\end{array}$ & & $\begin{array}{c}.925 \\
(.678)\end{array}$ & & $\begin{array}{l}1.717 \\
(.790)\end{array}$ & & $\begin{array}{r}2.937^{1} \\
(1.877)\end{array}$ & & $\begin{array}{l}.858 \\
(.351)\end{array}$ & & $\begin{array}{c}.003 \\
(.032)\end{array}$ \\
\hline Constant & $\begin{array}{l}.029 * * * \\
(.004)\end{array}$ & $\begin{array}{l}.031^{* * *} \\
(.004)\end{array}$ & $\begin{array}{l}.048^{* * *} \\
(.008)\end{array}$ & $\begin{array}{l}.052^{* * *} \\
(.009)\end{array}$ & $\begin{array}{l}.340^{* * *} \\
(.057)\end{array}$ & $\begin{array}{l}.361 * * * \\
(.057)\end{array}$ & $\begin{array}{l}.000^{* * *} \\
(.000)\end{array}$ & $\begin{array}{l}.000 * * * \\
(.000)\end{array}$ & $\begin{array}{c}.965 \\
(.023)\end{array}$ & $\begin{array}{l}.967 \\
(.023)\end{array}$ & $\begin{array}{l}-.781^{* * *} \\
(.031)\end{array}$ & $\begin{array}{l}-.783 * * * \\
(.031)\end{array}$ \\
\hline Controls included & yes & yes & yes & yes & yes & yes & yes & yes & yes & yes & yes & yes \\
\hline Year trend included & yes & yes & yes & yes & yes & yes & yes & yes & no & no & yes & yes \\
\hline Band time included & no & no & no & no & no & no & no & no & yes & yes & no & no \\
\hline Band fixed effect included & no & no & no & no & no & no & no & no & no & no & yes & yes \\
\hline $\begin{array}{l}N \\
R^{2}\end{array}$ & $\begin{array}{r}72,642 \\
.070^{2}\end{array}$ & $\begin{array}{l}72,642 \\
.065^{2}\end{array}$ & $\begin{array}{l}72,255 \\
.078^{2}\end{array}$ & $\begin{array}{l}72,255 \\
.078^{2}\end{array}$ & $\begin{array}{l}72,381 \\
.135^{2}\end{array}$ & $\begin{array}{l}72,381 \\
.135^{2}\end{array}$ & $\begin{array}{r}22,820 \\
.068^{2}\end{array}$ & $\begin{array}{r}22,820 \\
.069^{2}\end{array}$ & 97,184 & 97,184 & $\begin{array}{r}71,817 \\
.111^{3}\end{array}$ & $\begin{array}{r}71,817 \\
.111^{3}\end{array}$ \\
\hline AIC & 34,232 & 34,249 & 19,199 & 19,210 & 23,710 & 23,720 & 3,515 & 3,512 & 49,931 & 49,934 & & \\
\hline $\mathrm{BIC}$ & 34,315 & 34,332 & 19,282 & 19,292 & 23,793 & 23,803 & 3,587 & 3,584 & 50,112 & 50,114 & & \\
\hline
\end{tabular}

Table 6: Models of forbidden triads with structural possibility of six measures of success. 


\section{DISCUSSION AND CONCLUSIONS}

Our findings indicated that forbidden triads - conjunctures of two dyadic histories - are consistent predictors of creative team success. Forbidden triads are better predictors than weak open triads, and much better than closed triads, or a distinctive instrument combination. The mechanism we proposed operating in such triads is generative tension: when musicians in the session recognize how the diverse styles they built up before can become a new tune. Recognition of a possibility and realization of a new tone happens at the same time and place, exploration of how styles can contrast and combine and the musical product is one and the same. As opposed to a formalist approach to networks that envisions a static circuitry of information flow, we think of network ties as dyadic histories, part of career sequences, sites of joint experimentation.

We think of teams as collectives composed of triads. A forbidden triad is an elementary location for discovering a new sound, but the team is the one that creates the product. How do forbidden triads fuel innovation at the team level? We argue for two distinct ways to aggregate forbidden triads to the team level, that represent two possible translations of triadic discovery to team performance. Our results show that the density of forbidden triads is a better predictor of success than the depth of forbidden triads. It seems that the number of innovative opportunities matter more than the profound nature of a novel combination. Several further questions could be explored here, along the lines of recent approaches to tie weight distribution (Bruggerman 2006): What is the role of weight inequity in the two legs of forbidden triads? Could weight inequity in closed triads be assets for innovation?

Forbidden triads are not just about recruiting a musician with an unexpected instrument, as we control for instrument diversity. Forbidden triads are also not merely high weight dyads, or indications of recruiting experienced musicians with many sessions under their belts, as we control for past experience as well. Forbidden triads density is also not just an expression of larger band size, where a larger session might need to reach out to talent not well connected to a core set of musicians, as we control for session size as well.

We argued for an informed diversity of dependent variables, partly because repeated tests lend more credibility to an argument, and also because success is a multi-dimensional phenomenon. We argue that for art-worlds the two relevant dimensions are the public (insiders or outsiders), and the mechanism of conferring (voice or trace). Forbidden triads density is the only variable that consistently predicts all combinations of success dimensions. Further questions could be explored about the nature in which one kind of success breeds another, to understand a Matthew effect in innovative success (Bol, de Vaan, and van de Rijt 2018). For example, Is being recognized by outside audiences should come before or after the recognition by insiders?

With a simulation approach we tested whether sessions that had no easy access yet included forbidden triads are more successful than those with forbidden triads that were easily available. We found evidence for voice-based success that conscious effort has an additional benefit. When it comes to judgment of quality, bands that recruit against their structural limitations have an advantage. We believe that network research is at risk of structural determinism, as opposed to structural possibilism: beyond assuming an immediate link between structure and outcomes, we aimed to test for the significance of agency. 
Our results can be easily applied to designing teams, where innovation is a goal. If the gravity of cohesion and homophily can be counter-acted by recruiting collaborators from diverse contexts, a team with forbidden triads can be composed. In general, an organization that allows, or encourages the cultivation of diverse communities for any individual, will generate overlapping communities, and forbidden triads that can be put to generative use in composing a team.

\section{APPENDIX A: BOOKS USED TO MEASURE MENTIONS OF JAZZ SESSIONS}

\begin{tabular}{|c|c|}
\hline Book & $\begin{array}{l}\text { Number of sessions } \\
\text { mentioned }\end{array}$ \\
\hline $\begin{array}{l}\text { Thom Holmes, 2005: Jazz (American Popular Music). New York, NY: Facts on } \\
\text { File. }\end{array}$ & 261 \\
\hline $\begin{array}{l}\text { Lewis Porter, Michael Ullman, and Edward Hazell, 1992: Jazz: From its Origins } \\
\text { to the Present. Upper Saddle River, NJ: Prentice Hall. }\end{array}$ & 220 \\
\hline $\begin{array}{l}\text { Benito De Mar-A Mox, 2002: El Jazz : de Nueva Orleans a Los Anos Ochenta. } \\
\text { Mexico City, Mexico: Fondo de Cultura Economica USA. }\end{array}$ & 175 \\
\hline $\begin{array}{l}\text { Leonard Lyons, 1980: The } 101 \text { Best Jazz Albums: A History of Jazz on Records. } \\
\text { New York, NY: W. Morrow. }\end{array}$ & 128 \\
\hline Gary Giddins, and Scott DeVeaux, 2009: Jazz. New York, NY: W. W. Norton. & 101 \\
\hline Alyn Shipton, 2008: A New History of Jazz. London, UK: Continuum. & 84 \\
\hline Ted Gioia, 1998: The History of Jazz. London, UK: Oxford University Press. & 80 \\
\hline $\begin{array}{l}\text { Brian Priestley, 1989: Jazz on Record: A History. London, UK: Hamish } \\
\text { Hamilton. }\end{array}$ & 78 \\
\hline Frank Tirro, 1993: Jazz: A History. New York, NY: W. W. Norton. & 75 \\
\hline Mark C. Girdley, 2008: Jazz Styles: History and Analysis. London, UK: Pearson. & 63 \\
\hline $\begin{array}{l}\text { James Lincoln Collier, 1979: The Making of Jazz: A Comprehensive History. } \\
\text { New York, NY: Dell. }\end{array}$ & 60 \\
\hline $\begin{array}{l}\text { Ben Ratliff, 2002: Jazz: A Critics's Guide to the } 100 \text { Most Important Recordings. } \\
\text { New York, NY: Times Books. }\end{array}$ & 59 \\
\hline $\begin{array}{l}\text { John Szwed, 2000: Jazz 101: A Complete Guide to Learning and Loving Jazz. } \\
\text { New York, NY: Hachette Book Group. }\end{array}$ & 51 \\
\hline $\begin{array}{l}\text { Richard M. Cook, and Brian Morton, 2006: The Penguin Guide to Jazz } \\
\text { Recordings. London, UK: Penguin Books. }\end{array}$ & 47 \\
\hline $\begin{array}{l}\text { Loren Schoenberg, 2002: The NPR Curious Listener's Guide to Jazz. New York, } \\
\text { NY: TarcherPerigee. }\end{array}$ & 47 \\
\hline $\begin{array}{l}\text { Gary Giddens, 2000: Riding On A Blue Note: Jazz And American Pop. Boston, } \\
\text { MA: Da Capo Press. }\end{array}$ & 19 \\
\hline Eric Hobsbawm, 2014: The Jazz Scene. London, UK: Faber and Faber. & 10 \\
\hline $\begin{array}{l}\text { Barry Kernfeld, 1997: What to Listen for in Jazz. New Haven, CT: Yale } \\
\text { University Press. }\end{array}$ & 9 \\
\hline $\begin{array}{l}\text { Scott DeVeaux, 1999: The Birth of Bebop: A Social and Musical History. } \\
\text { Oakland, CA: University of California Press. }\end{array}$ & 2 \\
\hline $\begin{array}{l}\text { Ben Ratcliff, 2002: Jazz: A Critics's Guide to the } 100 \text { most important recordings. } \\
\text { New York, NY: Times Books. }\end{array}$ & 1 \\
\hline Total & 1670 \\
\hline
\end{tabular}

Table 7: Books used to measure mentions of jazz sessions. 


\section{REFERENCES}

Ahuja, Gautam. 2000. "Collaboration Networks, Structural Holes, and Innovation: A Longitudinal Study." Administrative Science Quarterly 45(3):425.

Allison, Paul D. 2009. "Missing Data." Pp. 72-89 in The SAGE Handbook of Quantitative Methods in Psychology, edited by R. E. Millsap and A. Maydeu-Olivares. Sage Publications.

Aral, Sinan and Marshall Van Alstyne. 2011. "The Diversity-Bandwidth Trade-Off." American Journal of Sociology 117(1):90-171.

Askin, Noah and Michael Mauskapf. 2017. "What Makes Popular Culture Popular? Product Features and Optimal Differentiation in Music." American Sociological Review 82(5):910-944.

Balachandran, Sarath and Exequiel Hernandez. 2018. "Networks and Innovation: Accounting for Structural and Institutional Sources of Recombination in Brokerage Triads." Organization Science 29(1):80-99.

Barrett, Frank J. 2012. Yes to the MessSurprising Leadership Lessons from Jazz. Harvard Business Press.

Becker, Howard, S. 1982. Art Worlds. University of California Press.

Berliner, Paul F. 1994. Thinking in Jazz: The Infinite Art of Improvisation. University of Chicago Press.

Bol, Thijs, Mathijs de Vaan, and Arnout van de Rijt. 2018. "The Matthew Effect in Science Funding." Proceedings of the National Academy of Sciences 115(19):4887-90.

Bourdieu, Pierre. 1996. The Rules of Art: Genesis and Structure of the Literary Field. Stanford University Press.

Bourdieu, Pierre and Randal Johnson. 1993. The Field of Cultural Production : Essays on Art and Literature. Columbia University Press.

Bruggerman, Jeroen. 2006. "The Strength of Varying Ties Strength: Comment on Aral and Van Alstyne." American Journal of Sociology 112(6):1919-1930.

Burt, Ronald S. 1995. Structural Holes: The Social Structure of Competition. 1. Harvard Univ. Press paperback ed. Cambridge, Mass.: Harvard Univ. Press.

Burt, Ronald S. 2005. Brokerage and Closure. An Introduction to Social Capital. New York: Oxford University Press.

Burt, Ronald S. 2015. "Reinforced Structural Holes.” Social Networks 43:149-161.

Burt, Ronald S., William Barnett, James Baron, Jon-Athan Bendor, Jack Birner, Matthew Bothner, Frank Dobbin, Chip Heath, Rachel Kranton, Rakesh Khurana, Jeffrey Pfeffer, Joel Podolny, Holly Raider, James Rauch, and Ron Burt. 2004. "Structural Holes and Good Ideas 1.” Ajs 110(2):349-99. 
Cattani, Gino, Simone Ferriani, and Paul D. Allison. 2014. "Insiders, Outsiders, and the Struggle for Consecration in Cultural Fields." American Sociological Review 79(2):258-81.

Cerulo, Karen A. 2008. Never Saw It Coming: Cultural Challenges to Envisioning the Worst. Chicago: University of Chicago Press.

Charry, Eric. 2005. "Reviewed Work ( s ): The Jazz Discography, Version 4 . 4 [ CD-ROM ] by Tom Lord ; 85 Years of Recorded Jazz ( 1917-2002, A-Z Complete ) [ CD-ROM ] by Walter Bruyninckx and Domi Truffandier." Notes 61(3):833-837.

Davis, Miles. and with Quincy Troupe. 1989. The Autobiography. Simon and Schuster.

De Vaan, Mathijs, David Stark, and Balazs Vedres. 2015. "Game Changer: The Topology of Creativity." American Journal of Sociology 120(4):1-51.

Deken, Fleur, Paul R. Carlile, Hans Berends, and Kristina Lauche. 2016. "Generating Novelty Through Interdependent Routines: A Process Model of Routine Work." Organization Science 27(3):659-77.

Delmar, Frédéric and Scott Shane. 2006. "Does Experience Matter? The Effect of Founding Team Experience on the Survival and Sales of Newly Founded Ventures." Strategic Organization 4(3):215-47.

DiBenigno, Julia and Katherine C. Kellogg. 2014. "Beyond Occupational Differences: The Importance of Cross-Cutting Demographics and Dyadic Toolkits for Collaboration in a U.S. Hospital.” Administrative Science Quarterly 59(3):375-408.

Dockery, Ben. 2013. Conceptualizing the Jazz Piano Trio: Interviews and Analysis with Nine Jazz Legends. CreateSpace Independent Publishing Platform.

Doffman, Mark. 2011. 'Jammin' an Ending: Creativity, Knowledge, and Conduct among Jazz Musicians." Twentieth-Century Music 8(02):203-225.

Dowd, Timothy J. and Diogo L. Pinheiro. 2013. "The Ties Among the Notes: The Social Capital of Jazz Musicians in Three Metro Areas." Work and Occupations 40(4):431464.

Emirbayer, Mustafa and Mimi Sheller. 1999. "Publics in History." Theory and Society 28(1):727-79.

Erikson, Emily. 2016. "Formalist and Relationalist Theory in Social Network Analysis." Sociological Theory 31(3):219-42.

Fabiani, Jean-Louis. 2003. "The Audience and Its Legend: A Sociological Analysis of the Avignon Festival.” The Journal of Arts Management, Law, and Society 32(4):265-77.

Fararo, Thomas J. 1983. "Biased Networks and the Strength of Weak Ties." Social Networks $5(1): 1-11$.

Faulkner, Robert R. and Howard Saul Becker. 2009. “Do You Know...?”: The Jazz Repertoire in Action. University of Chicago Press. 
Giddins, Gary. and Scott Knowles. DeVeaux. 2009. Jazz. W.W. Norton.

Granell, Clara, Richard K. Darst, Alex Arenas, Santo Fortunato, and Sergio Gómez. 2015. "Benchmark Model to Assess Community Structure in Evolving Networks." Physical Review E 92(1):012805.

Granovetter, Mark. 1973. "The Strength of Weak Ties.” American Journal of Sociology 78(6):1360-80.

Hume, David. 2015. The Philosophical Works of David Hume. New York: Arkose Press.

King, Gary and Langche Zeng. 2001. "Logistic Regression in Rare Events Data." Political Analysis 9(2):137-63.

Kor, Yasemin Y. 2003. "Experience-Based Top Management Team Competence and Sustained Growth.” Organization Science 14(6):707-19.

Krackhardt, David. 1999. "The Ties That Torture: Simmelian Tie Analysis in Organizations." Research in the Sociology of Organizations 16:183-210.

Krackhardt, David and Martin Kilduff. 2002. "Structure, Culture and Simmelian Ties in Entrepreneurial Firms." Social Networks 24(3):279-290.

Lizardo, Omar. 2017. "Improving Cultural Analysis: Considering Personal Culture in Its Declarative and Nondeclarative Modes." American Sociological Review 82(1):88115.

Lord, Tom. 2010. The Jazz Discography. Vancouver, Canada: Lord Music Reference Inc.

Obstfeld, David. 2005. "Social Networks, the Tertius Iungens Orientation, and Involvement in Innovation." Administrative Science Quarterly 50(1):100-130.

O’leary, Michael Boyer, Mark Mortensen, and Anita Williams Woolley. 2011. "Multiple Team Membership: A Theoretical Model of Its Effects on Productivity and Learning for Individuals and Teams." Academy of Management Review 36(3):461-478.

Onnela, Jukka Pekka, Jari Saramäki, János Kertész, and Kimmo Kaski. 2005. "Intensity and Coherence of Motifs in Weighted Complex Networks." Physical Review E Statistical, Nonlinear, and Soft Matter Physics 71(6):1-4.

Opsahl, Tore and Pietro Panzarasa. 2009. "Clustering in Weighted Networks." Social Networks 31(2):155-63.

Pattison, Philippa and Garry Robins. 2002. "Neighborhood-Based Models for Social Networks.” Sociological Methodology 32(1):301-37.

Phillips, Damon J. 2013. Shaping Jazz : Cities, Labels, and the Global Emergence of an Art Form. Princeton:NJ: Princeton University Press.

Podolny, Joel M. (Joel Marc). 2008. Status Signals : A Sociological Study of Market Competition. Princeton University Press. 
Reagans, R. E. and E. W. Zuckerman. 2008. "Why Knowledge Does Not Equal Power: The Network Redundancy Trade-Off." Industrial and Corporate Change 17(5):903-44.

Reagans, Ray and Bill McEvily. 2003. "Network Structure and Knowledge Transfer: The Effects of Cohesion and Range." Administrative Science Quarterly 48(2):240.

Romero, Daniel M., Brian Uzzi, and Jon Kleinberg. 2019. "Social Networks under Stress: Specialized Team Roles and Their Communication Structure." ACM Transactions on the Web 13(1):1-24.

Saramäki, Jari, Mikko Kivelä, Jukka Pekka Onnela, Kimmo Kaski, and János Kertész. 2007. "Generalizations of the Clustering Coefficient to Weighted Complex Networks." Physical Review E - Statistical, Nonlinear, and Soft Matter Physics 75(2):2-5.

Tilly, Charles. 2000. “How Do Relations Store Histories?” Annual Review of Sociology 26(1):721-23.

Tutić, Andreas and Harald Wiese. 2015. "Reconstructing Granovetter's Network Theory." Social Networks 43:136-48.

Uzzi, Brian and Jarrett Spiro. 2005. "Collaboration and Creativity: The Small World Problem." American Journal of Sociology 111(2):447-504.

Vaughan, Diane. 2016. The Challenger Launch Decision: Risky Technology, Culture, and Deviance at NASA. Chicago ; London: The University of Chicago Press.

Vedres, Balazs. 2017. "Forbidden Triads and Creative Success in Jazz: The Miles Davis Factor." Http://Arxiv.Org/Abs/1709.03787 2(1):31.

Vedres, Balazs and David Stark. 2010. "Structural Folds : Generative Disruption In." American Journal of Sociology 115(4):1150-90.

Vera, Dusya and Mary Crossan. 2005. "Improvisation and Innovative Performance in Teams.” Organization Science 16(3):203-24.

Walser, Robert. 1993. "Out of Notes : Interpretation, Signification, Problem Davis and the of Miles." The Musical Quarterly 77(2):343-365.

West, Aaron J. 2008. "Caught Between Jazz and Pop: The Contested Origins, Criticism, Performance Practice, and Reception of Smooth Jazz." University of North Texas.

White, Harrison C. 2002. Markets from Networks : Socioeconomic Models of Production. Princeton University Press.

White, Harrison C. and Cynthia A. White. 1993. Canvases and Careers: Institutional Change in the French Painting World. Chicago, IL: University of Chicago Press.

Wickham, Hadley. 2009. Ggplot2: Elegant Graphics for Data Analysis. Springer-Verlag.

Wuchty, Stefan, Benjamin F. Jones, and Brian Uzzi. 2007. "The Increasing Dominance of Teams in Production of Knowledge." Science 316(5827):1036-9. 
Xie, Jierui, Stephen Kelley, and Boleslaw K. Szymanski. 2013. "Overlapping Community Detection in Networks." ACM Computing Surveys 45(4):1-35.

Yang, Yang, Yuxiao Dong, and Nitesh V Chawla. 2014. "Predicting Node Degree Centrality with the Node Prominence Profile." Scientific Reports 4:7236.

Zerubavel, Eviatar. 2015. Hidden in Plain Sight: The Social Structure of Irrelevance. Oxford; New York, NY: Oxford University Press. 


\section{SUPPLEMENTARY MATERIAL}

\begin{tabular}{|c|c|c|c|c|c|c|c|c|c|c|c|c|c|c|c|}
\hline & (1) & (2) & (3) & (4) & (5) & (6) & (7) & (8) & (9) & (I) & (II) & (III) & (IV) & (V) & (VI) \\
\hline \multicolumn{16}{|l|}{ Independent variables } \\
\hline (1) Forbidden triads density & 1.000 & & & & & & & & & & & & & & \\
\hline (2) Forbidden triads depth & .803 & 1.000 & & & & & & & & & & & & & \\
\hline (3) Open triads density & -.091 & .006 & 1.000 & & & & & & & & & & & & \\
\hline (4) Closed triads density & -.492 & -.465 & -.822 & 1.000 & & & & & & & & & & & \\
\hline (5) $\mathrm{N}$ musicians & -.018 & .024 & .056 & -.039 & 1.000 & & & & & & & & & & \\
\hline (6) Session tenure & .238 & .120 & .101 & -.224 & .217 & 1.000 & & & & & & & & & \\
\hline (7) Median co-plays & -.053 & -.067 & -.189 & .195 & -.077 & .105 & 1.000 & & & & & & & & \\
\hline (8) Release history & .071 & .044 & .009 & -.048 & .020 & .146 & .074 & 1.000 & & & & & & & \\
\hline (9) Distinctiveness & -.061 & -.069 & -.062 & .089 & -.085 & -.147 & .000 & -.268 & 1.000 & & & & & & \\
\hline \multicolumn{16}{|l|}{ Dependent variables } \\
\hline (I) NEA Award & .057 & .036 & .014 & -.044 & .025 & .178 & .048 & .156 & -.062 & 1.000 & & & & & \\
\hline (II) Critics' Poll & .027 & .015 & -.001 & -.015 & .020 & .086 & .030 & .129 & -.049 & .284 & 1.000 & & & & \\
\hline (III) Readers' Poll & .040 & .017 & -.020 & -.005 & .007 & .109 & .094 & .195 & -.114 & .339 & -.040 & 1.000 & & & \\
\hline (IV) Book mention & .019 & .012 & .005 & -.015 & -.016 & .025 & .019 & .076 & -.038 & .109 & .049 & .164 & 1.000 & & \\
\hline (V) Band failure & -.049 & -.039 & -.004 & .031 & .034 & -.085 & -.073 & -.131 & .025 & -.105 & -.068 & -.086 & -.026 & 1.000 & \\
\hline (VI) Releases & .038 & .028 & .011 & -.032 & .041 & .072 & .019 & .256 & -.029 & .098 & .101 & .166 & .098 & -.083 & 1.000 \\
\hline
\end{tabular}

Table SI 1: Correlations table.

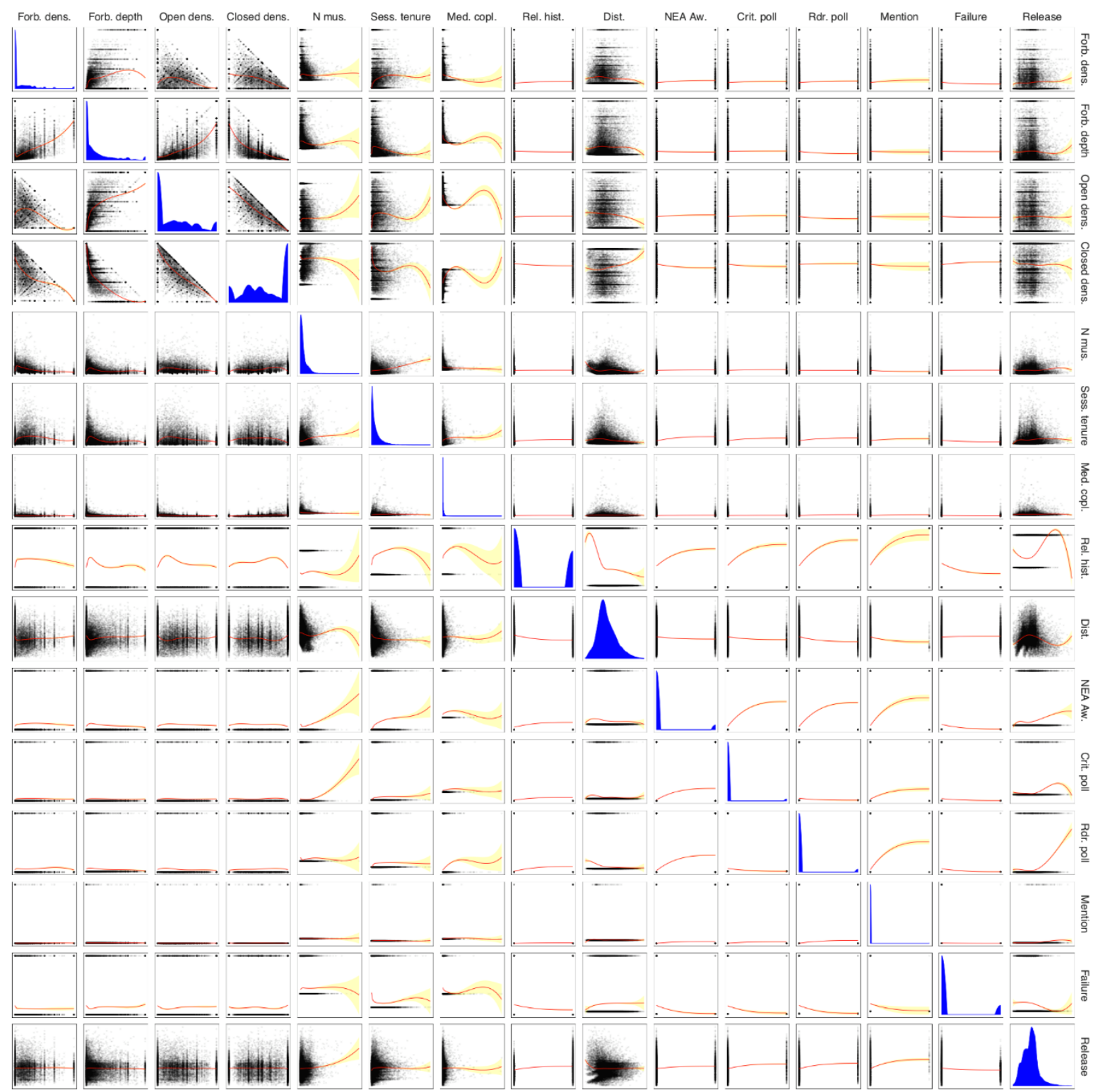

Figure SI 1: Scatterplot matrix of all variables used. Diagonal cells contain univariate density plots using the Epanechnikov kernel with the normal scale rule. Off diagonal cells show spline smoothing (red curve) with 95\% confidence interval (yellow area), and scatterplot. 


\begin{tabular}{|c|c|c|c|c|c|c|}
\hline & \multicolumn{6}{|c|}{ I. NEA Award } \\
\hline & 1: original ${ }^{1}$ & $\begin{array}{c}\text { 1b: standar- } \\
\text { dized }^{2}\end{array}$ & $\begin{array}{l}\text { 1c: band } \\
\text { level }^{3}\end{array}$ & 2: original $^{1}$ & $\begin{array}{c}\text { 2b: standar- } \\
\text { dized }^{2}\end{array}$ & $\begin{array}{c}\text { 2c: band } \\
\text { level }^{3}\end{array}$ \\
\hline Forbidden triads density & $\begin{array}{l}1.424 * * * \\
(.097)\end{array}$ & $\begin{array}{l}1.063 * * * \\
(.012)\end{array}$ & $\begin{array}{l}3.013 * * * \\
(.587)\end{array}$ & & & \\
\hline Forbidden triads depth & & & & $\begin{array}{l}1.558 * * * \\
(.119)\end{array}$ & $\begin{array}{l}1.072 * * * \\
(.013)\end{array}$ & $\begin{array}{l}3.140 * * * \\
(.702)\end{array}$ \\
\hline $\mathrm{N}$ musicians & $\begin{array}{l}.993 * * * \\
(.002)\end{array}$ & $\begin{array}{l}.955 * * * \\
(.013)\end{array}$ & $\begin{array}{c}.985 \\
(.014)\end{array}$ & $\begin{array}{l}.992 * * * \\
(.002)\end{array}$ & $\begin{array}{l}.951 * * * \\
(.013)\end{array}$ & $\begin{array}{l}.983 \\
(.014)\end{array}$ \\
\hline Session tenure & $\begin{array}{l}1.001 * * * \\
(.000)\end{array}$ & $\begin{array}{l}1.384 * * * \\
(.014)\end{array}$ & $\begin{array}{l}1.001 * * * \\
(.000)\end{array}$ & $\begin{array}{l}1.001 * * * \\
(.000)\end{array}$ & $\begin{array}{l}1.395 * * * \\
(.014)\end{array}$ & $\begin{array}{l}1.002 * * * \\
(.000)\end{array}$ \\
\hline Median co-plays & $\begin{array}{l}1.016 * * * \\
(.003)\end{array}$ & $\begin{array}{l}1.062 * * * \\
(.010)\end{array}$ & $\begin{array}{l}1.063 * * \\
(.021)\end{array}$ & $\begin{array}{l}1.017 * * * \\
(.003)\end{array}$ & $\begin{array}{l}1.062 * * * \\
(.010)\end{array}$ & $\begin{array}{l}1.062 * * \\
(.021)\end{array}$ \\
\hline Release history & $\begin{array}{l}3.155^{* * * *} \\
(.120)\end{array}$ & $\begin{array}{l}1.696 * * * \\
(.030)\end{array}$ & $\begin{array}{l}8.165 * * * \\
(1.157)\end{array}$ & $\begin{array}{l}3.154 * * * \\
(.120)\end{array}$ & $\begin{array}{l}1.669 * * * \\
(.029)\end{array}$ & $\begin{array}{l}8.150 * * * \\
(1.162)\end{array}$ \\
\hline Distinctiveness & $\begin{array}{l}.602 * * \\
(.111)\end{array}$ & $\begin{array}{l}.941 * * \\
(.021)\end{array}$ & $\begin{array}{l}.304 \\
(.268)\end{array}$ & $\begin{array}{l}.620^{*} \\
(.114)\end{array}$ & $\begin{array}{l}.944 * * * \\
(.020)\end{array}$ & $\begin{array}{l}.322 \\
(.286)\end{array}$ \\
\hline Year trend & $\begin{array}{l}1.004 * * * \\
(.001)\end{array}$ & $\begin{array}{l}1.093 * * * \\
(.025)\end{array}$ & $\begin{array}{l}1.016 * * * \\
(.003)\end{array}$ & $\begin{array}{l}1.004 * * * \\
(.001)\end{array}$ & $\begin{array}{l}1.090 * * * \\
(.025)\end{array}$ & $\begin{array}{l}1.016^{* * * *} \\
(.003)\end{array}$ \\
\hline Constant & $\begin{array}{l}.028 * * * \\
(.004)\end{array}$ & $\begin{array}{l}.050 * * * \\
(.001)\end{array}$ & $\begin{array}{l}.001 * * * \\
(.001)\end{array}$ & $\begin{array}{l}.028 * * * \\
(.004)\end{array}$ & $\begin{array}{l}.049 * * * \\
(.001)\end{array}$ & $\begin{array}{l}.001 * * * \\
(.000)\end{array}$ \\
\hline$N$ & 72,642 & 72,642 & 16,146 & 72,642 & 72,642 & 16,146 \\
\hline$R^{2}$ & $.085^{4}$ & $.085^{4}$ & $.123^{4}$ & $.085^{4}$ & $.085^{4}$ & $.122^{4}$ \\
\hline $\mathrm{AIC}$ & 34,225 & 34,225 & 1,206 & 34,219 & 34,219 & 1,207 \\
\hline $\mathrm{BIC}$ & 34,299 & 34,299 & 1,268 & 34,293 & 34,293 & 1,268 \\
\hline
\end{tabular}

Notes: The original models are the ones presented in the main text of the article.

1: Coefficients from maximum likelihood models with logistic function. Standard errors are in parentheses.

2: Coefficients from maximum likelihood models with logistic function. Independent variables are standardized.

3: Penalized maximum likelihood models with rare events correction (fit statistics are from refitted ML model).

4: Adjusted McFadden pseudo R-squared reported.

$*: \mathrm{p}<0.05 ; * *: \mathrm{p}<0.01 ; * * *: \mathrm{p}<0.001$

Table SI 2: Full models and alternative specifications for "NEA Award." Corresponds to Table 5 in the main text of the article. 


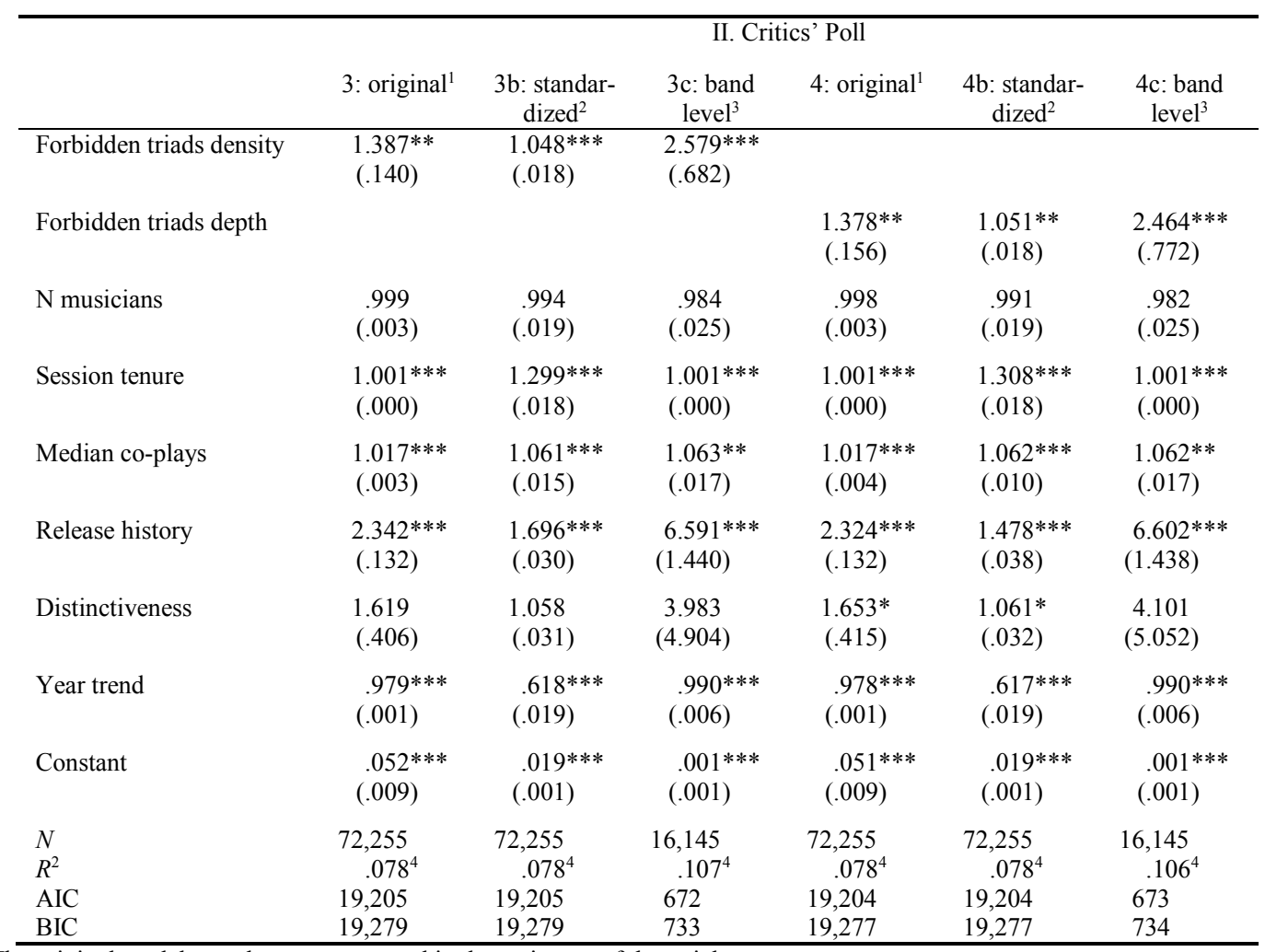

Notes: The original models are the ones presented in the main text of the article.

1: Coefficients from maximum likelihood models with logistic function. Standard errors are in parentheses.

2: Coefficients from maximum likelihood models with logistic function. Independent variables are standardized.

3: Penalized maximum likelihood models with rare events correction (fit statistics are from refitted ML model).

4: Adjusted McFadden pseudo R-squared reported.

$*: \mathrm{p}<0.05 ; * *: \mathrm{p}<0.01 ; * * *: \mathrm{p}<0.001$

Table SI 3: Full models and alternative specifications for "Critics' Poll." Corresponds to Table 5 in the main text of the article. 


\begin{tabular}{|c|c|c|c|c|c|c|}
\hline & \multicolumn{6}{|c|}{ III. Readers' Poll } \\
\hline & 5: original ${ }^{1}$ & $\begin{array}{c}\text { 5b: standar- } \\
\text { dized }^{2}\end{array}$ & $\begin{array}{l}\text { 5c: band } \\
\text { level }^{3}\end{array}$ & 6: original ${ }^{1}$ & $\begin{array}{c}\text { 6b: standar- } \\
\text { dized }^{2}\end{array}$ & $\begin{array}{l}\text { 6c: band } \\
\text { level }^{3}\end{array}$ \\
\hline Forbidden triads density & $\begin{array}{l}1.476^{* * * *} \\
(.125)\end{array}$ & $\begin{array}{l}1.048^{* * *} \\
(.018)\end{array}$ & $\begin{array}{l}2.579 * * * \\
(.682)\end{array}$ & & & \\
\hline Forbidden triads depth & & & & $\begin{array}{l}1.378 * * \\
(.156)\end{array}$ & $\begin{array}{l}1.051 * * \\
(.018)\end{array}$ & $\begin{array}{l}2.464 * * * \\
(.772)\end{array}$ \\
\hline $\mathrm{N}$ musicians & $\begin{array}{l}.985 * * * \\
(.032)\end{array}$ & $\begin{array}{l}.994 * * * \\
(.019)\end{array}$ & $\begin{array}{l}.984 \\
(.025)\end{array}$ & $\begin{array}{l}.998 \\
(.003)\end{array}$ & $\begin{array}{l}.991 \\
(.019)\end{array}$ & $\begin{array}{l}.982 \\
(.025)\end{array}$ \\
\hline Session tenure & $\begin{array}{l}1.001 * * * \\
(.000)\end{array}$ & $\begin{array}{l}1.299 * * * \\
(.018)\end{array}$ & $\begin{array}{l}1.001^{* * * *} \\
(.000)\end{array}$ & $\begin{array}{l}1.001 * * * \\
(.000)\end{array}$ & $\begin{array}{l}1.308 * * * \\
(.018)\end{array}$ & $\begin{array}{l}1.001^{* * *} \\
(.000)\end{array}$ \\
\hline Median co-plays & $\begin{array}{l}1.042 * * * \\
(.003)\end{array}$ & $\begin{array}{l}1.061 * * * \\
(.015)\end{array}$ & $\begin{array}{l}1.063^{* *} \\
(.017)\end{array}$ & $\begin{array}{l}1.017 * * * \\
(.004)\end{array}$ & $\begin{array}{l}1.062 * * * \\
(.010)\end{array}$ & $\begin{array}{l}1.062 * * \\
(.017)\end{array}$ \\
\hline Release history & $\begin{array}{l}3.809 * * * \\
(.198)\end{array}$ & $\begin{array}{l}1.696 * * * \\
(.030)\end{array}$ & $\begin{array}{l}6.591 * * * \\
(1.440)\end{array}$ & $\begin{array}{l}2.324 * * * \\
(.132)\end{array}$ & $\begin{array}{l}1.478 * * * \\
(.038)\end{array}$ & $\begin{array}{l}6.602 * * * \\
(1.438)\end{array}$ \\
\hline Distinctiveness & $\begin{array}{l}.043 * * * \\
(.010)\end{array}$ & $\begin{array}{l}1.058 * * * \\
(.031)\end{array}$ & $\begin{array}{c}3.983 \\
(4.904)\end{array}$ & $\begin{array}{l}1.653^{*} \\
(.415)\end{array}$ & $\begin{array}{l}1.061^{*} \\
(.032)\end{array}$ & $\begin{array}{c}4.101 \\
(5.052)\end{array}$ \\
\hline Year trend & $\begin{array}{l}.983 * * * \\
(.001)\end{array}$ & $\begin{array}{l}.618 * * * \\
(.019)\end{array}$ & $\begin{array}{l}.990 * * * \\
(.006)\end{array}$ & $\begin{array}{l}.978 * * * \\
(.001)\end{array}$ & $\begin{array}{l}.617 * * * \\
(.019)\end{array}$ & $\begin{array}{l}.990 * * * \\
(.006)\end{array}$ \\
\hline Constant & $\begin{array}{l}.336 * * * \\
(.056)\end{array}$ & $\begin{array}{l}.019 * * * \\
(.001)\end{array}$ & $\begin{array}{l}.001 * * * \\
(.001)\end{array}$ & $\begin{array}{l}.051 * * * \\
(.009)\end{array}$ & $\begin{array}{l}.019 * * * \\
(.001)\end{array}$ & $\begin{array}{l}.001 * * * \\
(.001)\end{array}$ \\
\hline$N$ & 72,381 & 72,255 & 16,145 & 72,255 & 72,255 & 16,145 \\
\hline$R^{2}$ & $.136^{4}$ & $.136^{4}$ & $.107^{4}$ & $.136^{4}$ & $.136^{4}$ & $.106^{4}$ \\
\hline $\mathrm{AIC}$ & 23,701 & 19,205 & 672 & 19,204 & 19,204 & 673 \\
\hline $\mathrm{BIC}$ & 23,774 & 19,279 & 733 & 19,277 & 19,277 & 734 \\
\hline
\end{tabular}

Notes: The original models are the ones presented in the main text of the article.

1: Coefficients from maximum likelihood models with logistic function. Standard errors are in parentheses.

2: Coefficients from maximum likelihood models with logistic function. Independent variables are standardized.

3: Penalized maximum likelihood models with rare events correction (fit statistics are from refitted ML model).

4: Adjusted McFadden pseudo R-squared reported.

$*: \mathrm{p}<0.05 ; * *: \mathrm{p}<0.01 ; * * *: \mathrm{p}<0.001$

Table SI 4: Full models and alternative specifications for "Readers' Poll." Corresponds to Table 5 in the main text of the article. 


\begin{tabular}{|c|c|c|c|c|c|c|}
\hline & \multicolumn{6}{|c|}{ IV. Book mention 1940-1969 } \\
\hline & 7 : $^{\text {original }}{ }^{1}$ & $\begin{array}{l}\text { 7b: standar- } \\
\text { dized }^{2}\end{array}$ & $\begin{array}{c}\text { 7c: zero } \\
\text { inflated } \\
\mathrm{NB}^{3}\end{array}$ & 8: original $^{1}$ & $\begin{array}{c}\text { 8b: standar- } \\
\text { dized }^{2}\end{array}$ & $\begin{array}{c}\text { 8c: zero } \\
\text { inflated } \\
\mathrm{NB}^{3}\end{array}$ \\
\hline Forbidden triads density & $\begin{array}{l}1.761 * * \\
(.388)\end{array}$ & $\begin{array}{l}1.103 * * \\
(.042)\end{array}$ & $\begin{array}{c}.236 \\
(.331)\end{array}$ & & & \\
\hline Forbidden triads depth & & & & $\begin{array}{l}1.600 \dagger \\
(.398)\end{array}$ & $\begin{array}{l}1.090 \dagger \\
(.050)\end{array}$ & $\begin{array}{l}.311 \\
(.382)\end{array}$ \\
\hline $\mathrm{N}$ musicians & $\begin{array}{l}.963 * * * \\
(.013)\end{array}$ & $\begin{array}{l}.774 * * * \\
(.068)\end{array}$ & $\begin{array}{l}.031 \\
(.020)\end{array}$ & $\begin{array}{l}.961^{*} \\
(.017)\end{array}$ & $\begin{array}{l}.763^{*} \\
(.090)\end{array}$ & $\begin{array}{l}.031 \\
(.019)\end{array}$ \\
\hline Session tenure & $\begin{array}{l}1.000 \\
(.000)\end{array}$ & $\begin{array}{l}1.052 \\
(.037)\end{array}$ & $\begin{array}{l}-.001 * * \\
(.000)\end{array}$ & $\begin{array}{l}1.000 \\
(.000)\end{array}$ & $\begin{array}{l}1.090 \\
(.069)\end{array}$ & $\begin{array}{l}-.001 * * \\
(.000)\end{array}$ \\
\hline Median co-plays & $\begin{array}{l}1.016 * \\
(.007)\end{array}$ & $\begin{array}{l}1.059 * \\
(.026)\end{array}$ & $\begin{array}{l}.042^{*} \\
(.021)\end{array}$ & $\begin{array}{l}1.015 \\
(.010)\end{array}$ & $\begin{array}{l}1.063 \\
(.045)\end{array}$ & $\begin{array}{l}.042^{*} \\
(.021)\end{array}$ \\
\hline Release history & $\begin{array}{l}4.800 * * * \\
(.839)\end{array}$ & $\begin{array}{l}2.056 * * * \\
(.165)\end{array}$ & $\begin{array}{l}-.041 \\
(.331)\end{array}$ & $\begin{array}{l}4.819^{* * * *} \\
(.978)\end{array}$ & $\begin{array}{l}2.061 * * * \\
(.192)\end{array}$ & $\begin{array}{l}-.044 \\
(.330)\end{array}$ \\
\hline Distinctiveness & $\begin{array}{l}.173^{*} \\
(.124)\end{array}$ & $\begin{array}{l}.812^{*} \\
(.069)\end{array}$ & $\begin{array}{l}-1.685 \\
(1.268)\end{array}$ & $\begin{array}{l}.173^{*} \\
(.149)\end{array}$ & $\begin{array}{l}.861^{*} \\
(.063)\end{array}$ & $\begin{array}{l}-1.676 \\
(1.266)\end{array}$ \\
\hline Year trend & $\begin{array}{l}1.099 * * * \\
(.008)\end{array}$ & $\begin{array}{l}8.302 * * * \\
(1.357)\end{array}$ & $\begin{array}{l}-.139 * * * \\
(.023)\end{array}$ & $\begin{array}{l}1.099 * * * \\
(.012)\end{array}$ & $\begin{array}{l}2.022 * * * \\
(.166)\end{array}$ & $\begin{array}{l}-.138 * * * \\
(.023)\end{array}$ \\
\hline Constant & $\begin{array}{l}.000 * * * \\
(.000)\end{array}$ & $\begin{array}{l}.041 * * * \\
(.007)\end{array}$ & $\begin{array}{l}7.922 * * * \\
(1.668)\end{array}$ & $\begin{array}{l}.000 * * * \\
(.000)\end{array}$ & $\begin{array}{l}.011 * * * \\
(.001)\end{array}$ & $\begin{array}{l}7.833^{* * * *} \\
(1.658)\end{array}$ \\
\hline $\begin{array}{l}N \\
R^{2}\end{array}$ & $\begin{array}{r}22,820 \\
.068^{4}\end{array}$ & $\begin{array}{r}22,820 \\
.068^{4}\end{array}$ & 22,820 & $\begin{array}{r}22,820 \\
.068^{4}\end{array}$ & $\begin{array}{r}22,820 \\
.068^{4}\end{array}$ & 22,820 \\
\hline AIC & 3,511 & 3,511 & 4,531 & 3,513 & 3,513 & 4,531 \\
\hline $\mathrm{BIC}$ & 3,575 & 3,575 & 4,660 & 3,579 & 3,579 & 4,660 \\
\hline
\end{tabular}

Notes: The original models are the ones presented in the main text of the article.

1: Coefficients from penalized maximum likelihood models with rare events correction (fit statistics are from refitted ML model). Standard errors clustered for band are in parentheses.

2: Coefficients from penalized maximum likelihood models with rare events correction (fit statistics are from refitted ML

model). Independent variables are standardized; standard errors clustered for band are in parentheses.

3: Coefficients from the count model of a zero inflated negative binomial regression model. (Vuong test $Z=8.14$, indicating zero

inflation. Inflation model included controls only.)

4: Adjusted McFadden pseudo R-squared reported.

$\dagger: \mathrm{p}=.058^{*}: \mathrm{p}<0.05 ; * *: \mathrm{p}<0.01 ; * * *: \mathrm{p}<0.001$

Table SI 5: Full models and alternative specifications for "Book mention." Corresponds to Table 5 in the main text of the article. 


\begin{tabular}{|c|c|c|c|c|c|c|}
\hline & \multicolumn{6}{|c|}{ V. Survival } \\
\hline & 9: original $^{1}$ & $\begin{array}{c}\text { 9b: standar- } \\
\text { dized }^{2}\end{array}$ & $\begin{array}{c}\text { 9c: Cox } \\
\text { regression }{ }^{3}\end{array}$ & 10: original $^{1}$ & $\begin{array}{c}\text { 10b: standar- } \\
\text { dized }^{2}\end{array}$ & $\begin{array}{l}\text { 10c: Cox } \\
\text { regression }\end{array}$ \\
\hline Forbidden triads density & $\begin{array}{l}.854 * * \\
(.045)\end{array}$ & $\begin{array}{l}1.076 * * * \\
(.016)\end{array}$ & $\begin{array}{l}.741 * * * \\
(.039)\end{array}$ & & & \\
\hline Forbidden triads depth & & & & $\begin{array}{l}.821 * * * \\
(.044)\end{array}$ & $\begin{array}{l}1.067 * * * \\
(.014)\end{array}$ & $\begin{array}{l}.734 * * * \\
(.040)\end{array}$ \\
\hline $\mathrm{N}$ musicians & $\begin{array}{l}1.002 \\
(.001)\end{array}$ & $\begin{array}{l}.911 * * * \\
(.012)\end{array}$ & $\begin{array}{l}1.003 * \\
(.001)\end{array}$ & $\begin{array}{l}1.002 \\
(.001)\end{array}$ & $\begin{array}{l}.906 * * * \\
(.012)\end{array}$ & $\begin{array}{l}1.003 * * \\
(.001)\end{array}$ \\
\hline Session tenure & $\begin{array}{l}1.000 \\
(.000)\end{array}$ & $\begin{array}{l}1.187 * * * \\
(.010)\end{array}$ & $\begin{array}{l}1.000 * * * \\
(.000)\end{array}$ & $\begin{array}{l}1.000 \\
(.000)\end{array}$ & $\begin{array}{l}1.200 * * * \\
(.019)\end{array}$ & $\begin{array}{l}1.000 * * * \\
(.000)\end{array}$ \\
\hline Median co-plays & $\begin{array}{l}.999 \\
(.004)\end{array}$ & $\begin{array}{l}1.329 * * * \\
(.038)\end{array}$ & $\begin{array}{l}.995 \\
(.003)\end{array}$ & $\begin{array}{l}.999 \\
(.004)\end{array}$ & $\begin{array}{l}1.328 * * * \\
(.038)\end{array}$ & $\begin{array}{l}.995 \\
(.003)\end{array}$ \\
\hline Release history & $\begin{array}{l}.861 * * * \\
(.027)\end{array}$ & $\begin{array}{l}1.378 * * * \\
(.028)\end{array}$ & $\begin{array}{l}.845 * * * \\
(.026)\end{array}$ & $\begin{array}{l}.862 * * * \\
(.027)\end{array}$ & $\begin{array}{l}1.378 * * * \\
(.028)\end{array}$ & $\begin{array}{l}.844 * * * \\
(.026)\end{array}$ \\
\hline Distinctiveness & $\begin{array}{l}1.008 \\
(.102)\end{array}$ & $\begin{array}{l}1.123 * * * \\
(.024)\end{array}$ & $\begin{array}{l}1.173 \\
(.119)\end{array}$ & $\begin{array}{l}.999 \\
(.101)\end{array}$ & $\begin{array}{l}1.127 * * * \\
(.024)\end{array}$ & $\begin{array}{l}1.161 \\
(.118)\end{array}$ \\
\hline Year trend & $\begin{array}{l}1.019 * * * \\
(.001)\end{array}$ & $\begin{array}{l}.852 * * * \\
(.020)\end{array}$ & $\begin{array}{l}1.010^{* * * *} \\
(.001)\end{array}$ & $\begin{array}{l}1.019 * * * \\
(.001)\end{array}$ & $\begin{array}{l}.852 * * * \\
(.020)\end{array}$ & $\begin{array}{l}1.010 * * * \\
(.001)\end{array}$ \\
\hline Structural zero & $\begin{array}{l}.965 \\
(.023)\end{array}$ & & $\begin{array}{l}.911 * * * \\
(.001)\end{array}$ & $\begin{array}{l}.962 \\
(.023)\end{array}$ & & $\begin{array}{l}.909 * * * \\
(.001)\end{array}$ \\
\hline Constant & $\begin{array}{l}.218 * * * \\
(.001)\end{array}$ & $\begin{array}{l}11.628 * * * \\
(.211)\end{array}$ & & $\begin{array}{l}.219 * * * \\
(.019)\end{array}$ & $\begin{array}{l}11.630^{* * * *} \\
(.211)\end{array}$ & \\
\hline$N$ & 97,184 & 61,104 & 97,184 & 97,184 & 61,104 & 97,184 \\
\hline AIC & 49,928 & 33,885 & 221,370 & 49,923 & 33,889 & 221,370 \\
\hline $\mathrm{BIC}$ & 50,099 & 33,958 & 221,446 & 50,094 & 33,960 & 221,446 \\
\hline
\end{tabular}

Notes: The original models are the ones presented in the main text of the article.

1: From piecewise exponential regression models, we report hazard ratios and standard errors (in parentheses).

2: Coefficients from maximum likelihood models with logistic function predicting non-failure of the band after the session $(=1)$.

Independent variables are standardized. Standard errors clustered for band are in parentheses.

3: From Cox regression models, we report hazard ratios and standard errors (in parentheses).

$* \mathrm{p}<0.05 ; * * \mathrm{p}<0.01 ; * * * \mathrm{p}<0.001$ (two-tailed).

Table SI 6: Full models and alternative specifications for "Survival." Corresponds to Table 5 in the main text of the article. 


\begin{tabular}{|c|c|c|c|c|c|c|}
\hline & \multicolumn{6}{|c|}{ VI. Releases (per decade, log) } \\
\hline & 11: original $^{1}$ & $\begin{array}{l}\text { 11b: standar- } \\
\text { dized }^{2}\end{array}$ & $\begin{array}{c}\text { 11c: zero } \\
\text { inflated } \mathrm{NB}^{3}\end{array}$ & 12: original $^{1}$ & $\begin{array}{l}\text { 12b: standar- } \\
\text { dized }^{2}\end{array}$ & $\begin{array}{c}12 \mathrm{c}: \text { zero } \\
\text { inflated } \mathrm{NB}^{3}\end{array}$ \\
\hline Forbidden triads density & $\begin{array}{l}.018 * * * \\
(.005)\end{array}$ & $\begin{array}{l}1.097 * * \\
(.038)\end{array}$ & $\begin{array}{l}.187 * * \\
(.061)\end{array}$ & & & \\
\hline Forbidden triads depth & & & & $\begin{array}{l}.019 * * * \\
(.006)\end{array}$ & $\begin{array}{l}1.096^{*} \\
(.041)\end{array}$ & $\begin{array}{l}.187^{*} \\
(.087)\end{array}$ \\
\hline $\mathrm{N}$ musicians & $\begin{array}{l}.003 * * * \\
(.000)\end{array}$ & $\begin{array}{l}1.176^{*} \\
(.090)\end{array}$ & $\begin{array}{l}.009 * * \\
(.003)\end{array}$ & $\begin{array}{l}.002 * * * \\
(.000)\end{array}$ & $\begin{array}{l}1.170 * \\
(.091)\end{array}$ & $\begin{array}{l}.009 * * \\
(.003)\end{array}$ \\
\hline Session tenure & $\begin{array}{l}-.000 * * * \\
(.000)\end{array}$ & $\begin{array}{l}1.061 \\
(.050)\end{array}$ & $\begin{array}{l}-.000 \\
(.000)\end{array}$ & $\begin{array}{l}-.000 * * * \\
(.000)\end{array}$ & $\begin{array}{l}1.079 \\
(.050)\end{array}$ & $\begin{array}{l}-.000 \\
(.000)\end{array}$ \\
\hline Median co-plays & $\begin{array}{l}-.000 \\
(.000)\end{array}$ & $\begin{array}{l}1.096 * * \\
(.033)\end{array}$ & $\begin{array}{l}.004 \\
(.003)\end{array}$ & $\begin{array}{l}-.000 \\
(.000)\end{array}$ & $\begin{array}{l}1.095 * * \\
(.032)\end{array}$ & $\begin{array}{l}.004 \\
(.003)\end{array}$ \\
\hline Release history & $\begin{array}{l}.237 * * * \\
(.003)\end{array}$ & $\begin{array}{l}3.568 * * * \\
(.357)\end{array}$ & $\begin{array}{l}1.271 * * * \\
(.068)\end{array}$ & $\begin{array}{l}.237 * * * \\
(.003)\end{array}$ & $\begin{array}{l}3.570 * * * \\
(.358)\end{array}$ & $\begin{array}{l}1.272 * * * \\
(.068)\end{array}$ \\
\hline Distinctiveness & $\begin{array}{l}-.126 * * * \\
(.015)\end{array}$ & $\begin{array}{l}.675 * * * \\
(.057)\end{array}$ & $\begin{array}{l}-1.249^{* * *} \\
(.203)\end{array}$ & $\begin{array}{l}-.125 * * * \\
(.015)\end{array}$ & $\begin{array}{l}.680 * * * \\
(.058)\end{array}$ & $\begin{array}{l}-1.239 * * * \\
(.203)\end{array}$ \\
\hline Year trend & $\begin{array}{l}.006 * * * \\
(.000)\end{array}$ & $\begin{array}{l}.344 * * * \\
(.034)\end{array}$ & $\begin{array}{l}-.043 * * * \\
(.002)\end{array}$ & $\begin{array}{l}.006 * * * \\
(.000)\end{array}$ & $\begin{array}{l}.342 * * * \\
(.034)\end{array}$ & $\begin{array}{l}-.043 * * * \\
(.002)\end{array}$ \\
\hline Constant & $\begin{array}{l}-.795 * * * \\
(.014)\end{array}$ & $\begin{array}{l}.001 * * * \\
(.000)\end{array}$ & $\begin{array}{l}3.198 * * * \\
(.166)\end{array}$ & $\begin{array}{l}-.795 * * * \\
(.014)\end{array}$ & $\begin{array}{l}.001 * * * \\
(.000)\end{array}$ & $\begin{array}{l}3.194 * * * \\
(.164)\end{array}$ \\
\hline $\begin{array}{l}N \\
R^{2}\end{array}$ & $\begin{array}{r}71,817 \\
.110^{4}\end{array}$ & $\begin{array}{r}71,817 \\
.233^{5}\end{array}$ & 71,817 & $\begin{array}{r}71,817 \\
.110^{4}\end{array}$ & $\begin{array}{r}71,817 \\
.231^{5}\end{array}$ & 71,817 \\
\hline $\mathrm{AIC}$ & & 8,839 & 162,468 & & 8,839 & 162,473 \\
\hline $\mathrm{BIC}$ & & 8,912 & 162,615 & & 8,913 & 162,620 \\
\hline
\end{tabular}

Notes: The original models are the ones presented in the main text of the article.

1: Coefficients from OLS with fixed effects for band. Standard errors clustered for band are in parentheses.

2: Coefficients from maximum likelihood models with logistic function predicting top 5 percentile release variable $(=1)$, with

clustered standard errors for band. Independent variables are standardized. Standard errors clustered for band are in parentheses.

3: Coefficients from zero inflated negative binomial count model for the number of additional releases, with clustered standard

errors for band. Inflation model omitted (featured control variables only).

4: R-squared for within-band model.

5: McFadden pseudo R-squared.

$*: \mathrm{p}<0.05 ; * *: \mathrm{p}<0.01 ; * * *: \mathrm{p}<0.001$

Table SI 7: Full models and alternative specifications for "Releases." Corresponds to Table 5 in the main text of the article. 


\begin{tabular}{lcc}
\hline & \multicolumn{2}{c}{ VII. Deep success } \\
& 13 original $^{1}$ & 14 original $^{1}$ \\
\hline Forbidden triads density & $1.167^{*}$ & \\
& $(.071)$ & \\
Forbidden triads depth & & 1.114 \\
& & $(.108)$ \\
N musicians & .878 & .861 \\
& $(.306)$ & $(.304)$ \\
Session tenure & .973 & 1.004 \\
& $(.109)$ & $(.111)$ \\
Median co-plays & $1.164^{* * *}$ & $1.158^{* * *}$ \\
& $(.041)$ & $(.037)$ \\
Release history & $2.304^{* *}$ & $2.311^{* *}$ \\
& $(.651)$ & $(.658)$ \\
Distinctiveness & $.447^{* * *}$ & $.449^{* * *}$ \\
& $(.112)$ & $(.111)$ \\
Year trend & $.965^{* * *}$ & $.965^{* * *}$ \\
& $(.008)$ & $(.008)$ \\
Constant & $.006^{* * *}$ & $.007^{* * *}$ \\
& $(.005)$ & $(.005)$ \\
$N$ & 61,104 & 61,104 \\
$R^{2}$ & $.136^{2}$ & $.134^{2}$ \\
AIC & 1,750 & 1,752 \\
BIC & 1,822 & 1,825 \\
\hline
\end{tabular}

Notes: The original models are the ones presented in the main text of the article.

1: Coefficients from penalized maximum likelihood models with rare events correction (fit statistics are from refitted ML model). Independent variables are standardized; standard errors clustered for band are in parentheses.

2: McFadden pseudo R-squared.

$*: \mathrm{p}<0.05 ; * *: \mathrm{p}<0.01 ; * * *: \mathrm{p}<0.001$

Table SI 8: Full models for "Deep success." Point estimates for Forbidden triads density and depth are presented on Figure 4, column one and two, in the main text of the article. 

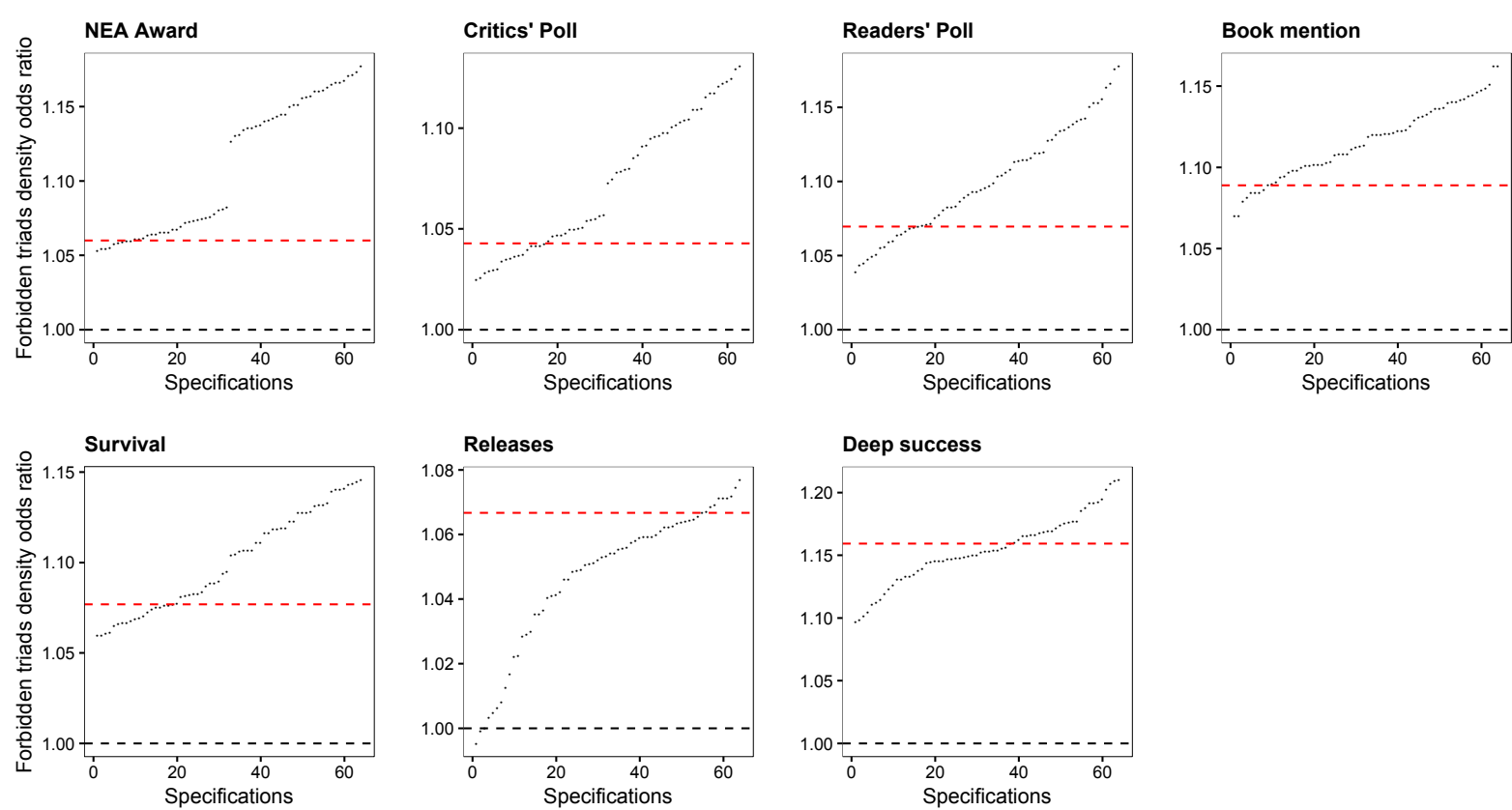

Figure SI 2: Specification curves for Forbidden triads density; standardized models. For each panel, specifications with all combinations of six control variables are sorted along the horizontal axis by the size of the Forbidden triads density odds ratio, that is on the vertical axis. Black dashed line is at odds ratio=1, red dashed line shows the odds ratio reported in the corresponding full model.
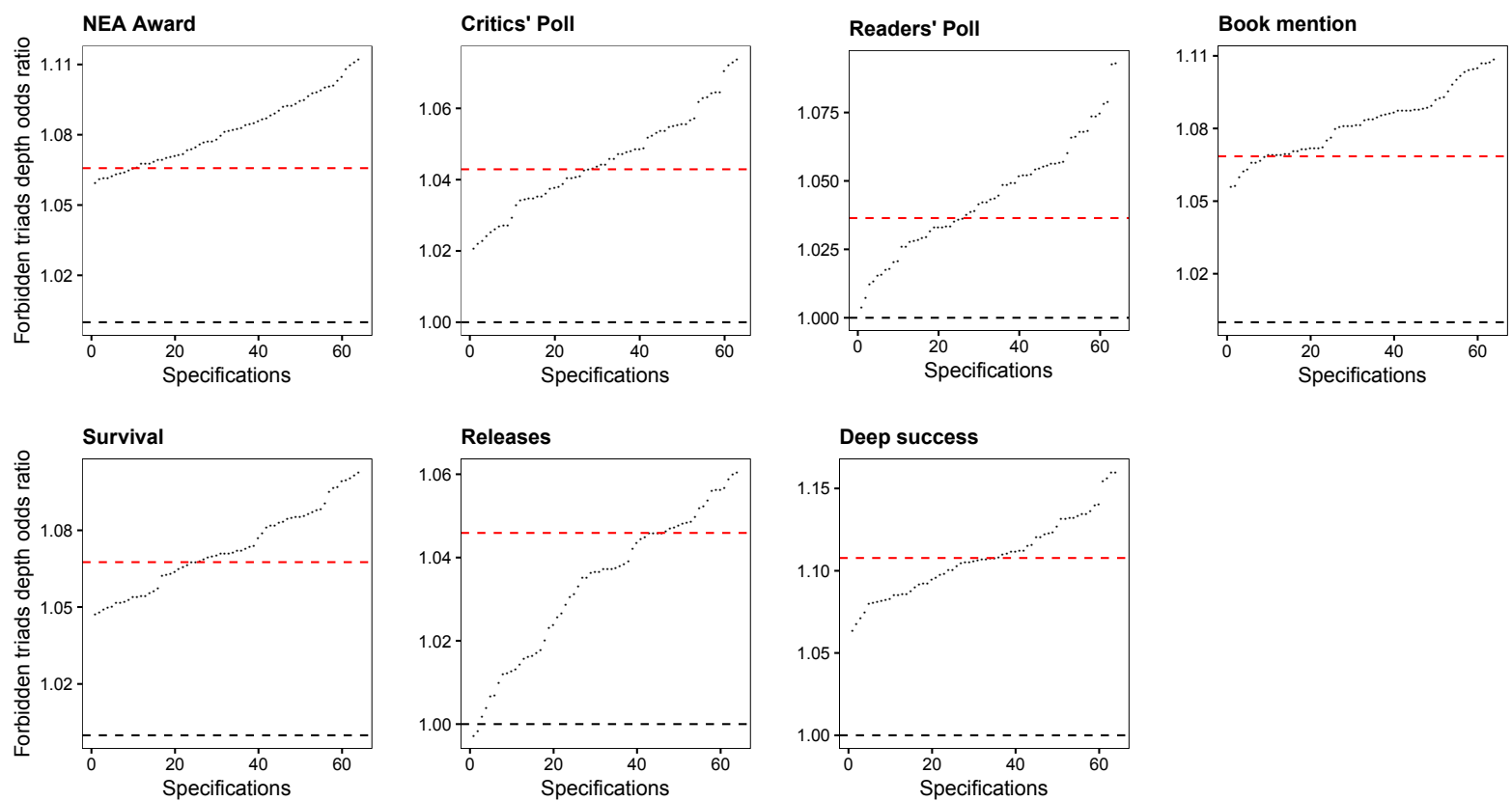

Figure SI 3: Specification curves for Forbidden triads depth; standardized models. For each panel, specifications with all combinations of six control variables are sorted along the horizontal axis by the size of the Forbidden triads depth odds ratio, that is on the vertical axis. Black dashed line is at odds ratio $=1$, red dashed line shows the odds ratio reported in the corresponding full model. 

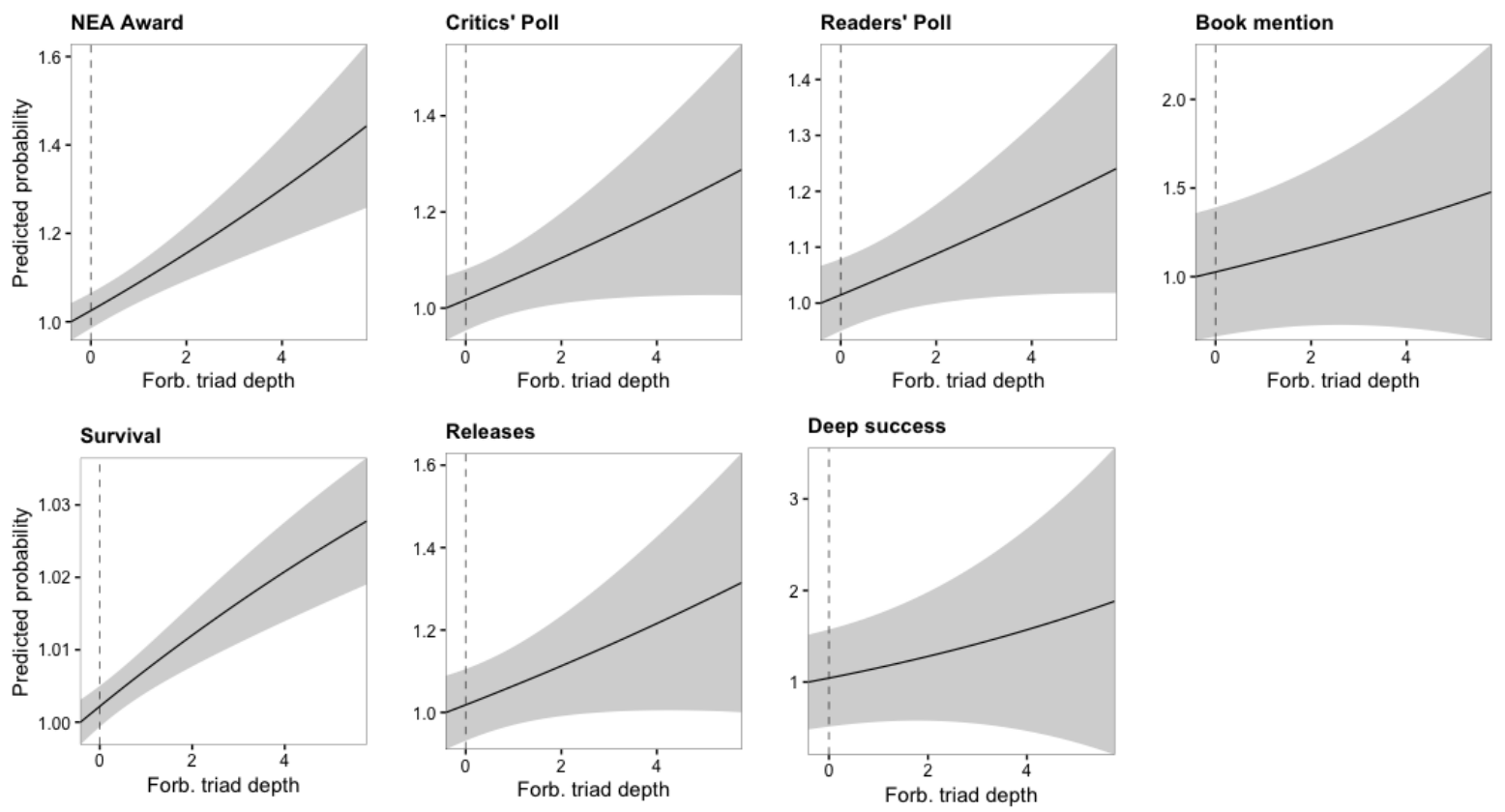

Figure SI 4: Marginal predictions for Forbidden triads density; standardized models. Each panel shows marginal predictions along the range of the standardized range of Forbidden triads density variable, with the mean marked by a vertical dashed line. The vertical axis shows relative predicted probability, with the prediction at the minimum of Forbidden triads density $=1$.
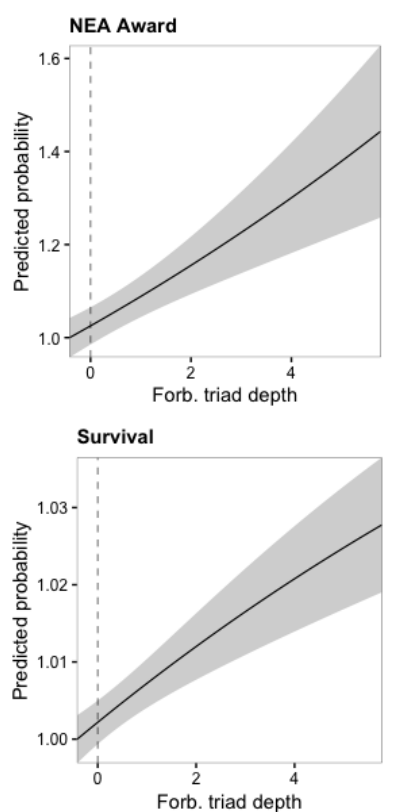
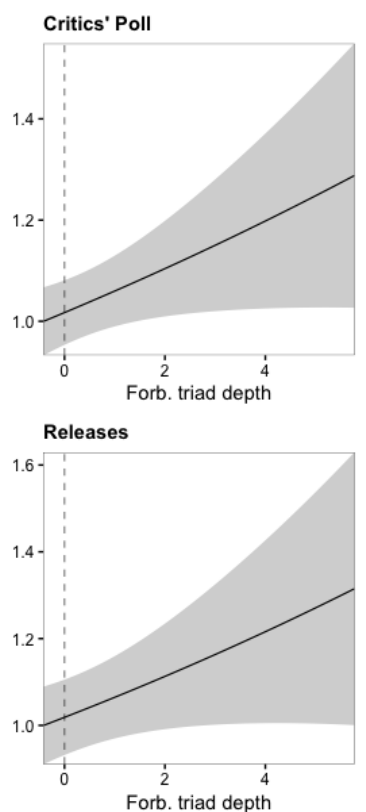
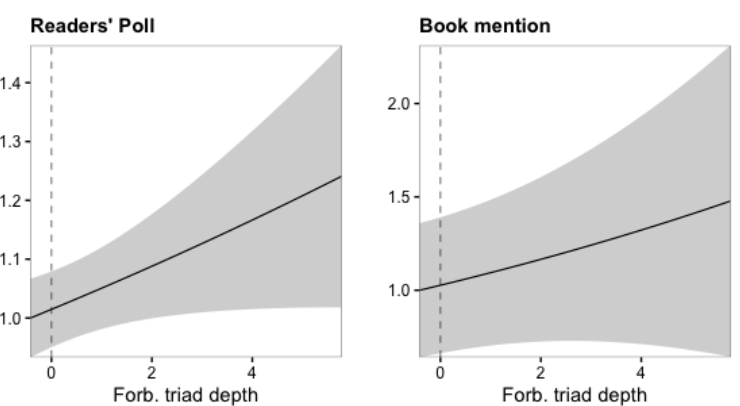

Deep success

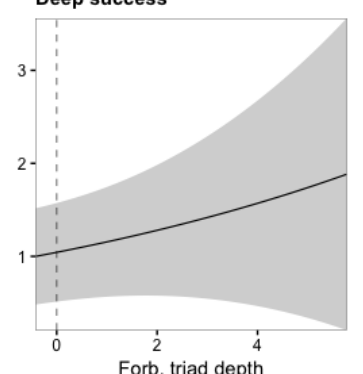

Figure SI 5: Marginal predictions for Forbidden triads depth; standardized models. Each panel shows marginal predictions along the range of the standardized range of Forbidden triads depth variable, with the mean marked by a vertical dashed line. The vertical axis shows relative predicted probability, with the prediction at the minimum of Forbidden triads depth $=1$. 


\begin{tabular}{|c|c|c|c|c|c|c|c|}
\hline & $\begin{array}{l}\text { I. NEA } \\
\text { Award }\end{array}$ & $\begin{array}{l}\text { II. Critics' } \\
\text { Poll }\end{array}$ & $\begin{array}{l}\text { III. Readers' } \\
\text { Poll }\end{array}$ & $\begin{array}{l}\text { IV. Book } \\
\text { mention }\end{array}$ & V. Survival & VI. Releases & $\begin{array}{c}\text { VII. Deep } \\
\text { success }\end{array}$ \\
\hline Weak open triads density & $\begin{array}{l}1.030 * \\
(.014)\end{array}$ & $\begin{array}{l}1.005 \\
(.021)\end{array}$ & $\begin{array}{l}.932 * * * \\
(.017)\end{array}$ & $\begin{array}{l}1.068 \\
(.052)\end{array}$ & $\begin{array}{l}1.042 * * \\
(.014)\end{array}$ & $\begin{array}{l}.038 \\
(.037)\end{array}$ & $\begin{array}{l}.892 \\
(.078)\end{array}$ \\
\hline $\mathrm{N}$ musicians & $\begin{array}{l}.900 * * * \\
(.013)\end{array}$ & $\begin{array}{l}.930 * * * \\
(.090)\end{array}$ & $\begin{array}{l}.803 * * * \\
(.016)\end{array}$ & $\begin{array}{l}.690 * * * \\
(.053)\end{array}$ & $\begin{array}{l}.893 * * * \\
(.012)\end{array}$ & $\begin{array}{l}.866^{* * * *} \\
(.028)\end{array}$ & $\begin{array}{l}.850 \\
(.095)\end{array}$ \\
\hline Session tenure & $\begin{array}{l}1.496^{* * * *} \\
(.014)\end{array}$ & $\begin{array}{l}1.380 * * * \\
(.020)\end{array}$ & $\begin{array}{l}1.413 * * * \\
(.017)\end{array}$ & $\begin{array}{l}1.155^{* * * *} \\
(.047)\end{array}$ & $\begin{array}{l}1.236^{* * * *} \\
(.020)\end{array}$ & $\begin{array}{l}1.257 * * * \\
(.035)\end{array}$ & $\begin{array}{l}1.017 \\
(.049)\end{array}$ \\
\hline Median co-plays & $\begin{array}{l}1.070 \\
(.011)\end{array}$ & $\begin{array}{l}1.056 * * * \\
(.015)\end{array}$ & $\begin{array}{l}1.156^{* * * *} \\
(.012)\end{array}$ & $\begin{array}{l}1.069^{*} \\
(.032)\end{array}$ & $\begin{array}{l}1.354 * * * \\
(.040)\end{array}$ & $\begin{array}{l}1.109 * * * \\
(.023)\end{array}$ & $\begin{array}{l}1.133^{* * * *} \\
(.031)\end{array}$ \\
\hline Release history & $\begin{array}{l}1.160 * * * \\
(.011)\end{array}$ & $\begin{array}{l}1.165^{* * * *} \\
(.012)\end{array}$ & $\begin{array}{l}1.280 * * * \\
(.013)\end{array}$ & $\begin{array}{l}1.237 * * * \\
(.031)\end{array}$ & $\begin{array}{l}1.727 * * * \\
(.072)\end{array}$ & $\begin{array}{l}1.861 * * * \\
(.031)\end{array}$ & $\begin{array}{l}2.329 * * * \\
(.410)\end{array}$ \\
\hline Distinctiveness & $\begin{array}{l}.930 * * * \\
(.020)\end{array}$ & $\begin{array}{l}1.033 \\
(.031)\end{array}$ & $\begin{array}{l}.667 * * * \\
(.019)\end{array}$ & $\begin{array}{l}.784 * * \\
(.068)\end{array}$ & $\begin{array}{l}1.140 * * * \\
(.025)\end{array}$ & $\begin{array}{l}.652 * * * \\
(.036)\end{array}$ & $\begin{array}{l}.440 * * * \\
(.072)\end{array}$ \\
\hline Year trend & $\begin{array}{l}.991 * * * \\
(.001)\end{array}$ & $\begin{array}{l}.972 * * * \\
(.001)\end{array}$ & $\begin{array}{l}.975 * * * \\
(.001)\end{array}$ & $\begin{array}{l}1.095^{* * * *} \\
(.010)\end{array}$ & $\begin{array}{l}.992 * * * \\
(.001)\end{array}$ & $\begin{array}{l}.961 * * * \\
(.002)\end{array}$ & $\begin{array}{l}.966 * * * \\
(.004)\end{array}$ \\
\hline Constant & $\begin{array}{l}.112 * * * \\
(.008)\end{array}$ & $\begin{array}{l}.208 * * * \\
(.019)\end{array}$ & $\begin{array}{l}.192 * * * \\
(.016)\end{array}$ & $\begin{array}{l}.000 * * * \\
(.000)\end{array}$ & $\begin{array}{l}24.136 * * * \\
(2.043)\end{array}$ & $\begin{array}{l}.073 * * * \\
(.012)\end{array}$ & $\begin{array}{l}.007 * * * \\
(.003)\end{array}$ \\
\hline $\begin{array}{l}N \\
R^{2} \\
\mathrm{AIC} \\
\mathrm{BIC}\end{array}$ & $\begin{array}{r}71,691 \\
.065^{3} \\
34,360 \\
34,434\end{array}$ & $\begin{array}{c}71,694 \\
.077^{3} \\
18,862 \\
18,935\end{array}$ & $\begin{array}{c}71,445 \\
.131^{3} \\
23,564 \\
23,638\end{array}$ & $\begin{array}{c}22,299 \\
.051^{3} \\
3,515 \\
3,579\end{array}$ & $\begin{array}{r}61,104 \\
.032^{3} \\
33,909 \\
33,981\end{array}$ & $\begin{array}{c}71,817 \\
.376^{3} \\
7,180 \\
7,253\end{array}$ & $\begin{array}{c}61,104 \\
.134^{3} \\
1,753 \\
1,825\end{array}$ \\
\hline
\end{tabular}

Notes: 1: Coefficients from maximum likelihood models with logistic function. Independent variables are standardized. Standard errors are in parentheses.

2: Penalized maximum likelihood models with rare events correction (fit statistics are from refitted ML model). Independent variables are standardized.

3: Adjusted McFadden pseudo R-squared reported.

$*: \mathrm{p}<0.05 ; * *: \mathrm{p}<0.01 ; * * *: \mathrm{p}<0.001$

Table SI 9: Models for the relationship between weak open triads and seven measures of success, including deep success. Point estimates for "Weak open triads density" are presented on Figure 4, column three, in the main text of the article. 


\begin{tabular}{|c|c|c|c|c|c|c|c|}
\hline & $\begin{array}{l}\text { I. NEA } \\
\text { Award }^{1}\end{array}$ & $\begin{array}{l}\text { II. Critics' } \\
\text { Poll }^{1} \\
\end{array}$ & $\begin{array}{l}\text { III. Readers' } \\
\text { Poll }^{1}\end{array}$ & $\begin{array}{l}\text { IV. Book } \\
\text { mention }^{1}\end{array}$ & V. Survival $^{1}$ & VI. Releases ${ }^{1}$ & $\begin{array}{l}\text { VII. Deep } \\
\text { success }^{2}\end{array}$ \\
\hline Closed triads density & $\begin{array}{l}.895 * * * \\
(.018)\end{array}$ & $\begin{array}{l}.942^{*} \\
(.021)\end{array}$ & $\begin{array}{l}1.003 \\
(.025)\end{array}$ & $\begin{array}{l}.810^{* *} \\
(.056)\end{array}$ & $\begin{array}{l}.895 * * * \\
(.017)\end{array}$ & $\begin{array}{l}.853 * * \\
(.042)\end{array}$ & $\begin{array}{l}.979 \\
(.105)\end{array}$ \\
\hline $\mathrm{N}$ musicians & $\begin{array}{l}.900 * * * \\
(.013)\end{array}$ & $\begin{array}{l}.930 * * * \\
(.090)\end{array}$ & $\begin{array}{l}.803 * * * \\
(.016)\end{array}$ & $\begin{array}{l}.699 * * * \\
(.054)\end{array}$ & $\begin{array}{l}.896 * * * \\
(.012)\end{array}$ & $\begin{array}{l}.874 * * * \\
(.029)\end{array}$ & $\begin{array}{c}.857 \\
(.096)\end{array}$ \\
\hline Session tenure & $\begin{array}{l}1.482 * * * \\
(.014)\end{array}$ & $\begin{array}{l}1.372 * * * \\
(.019)\end{array}$ & $\begin{array}{l}1.411 * * * \\
(.017)\end{array}$ & $\begin{array}{l}1.135 * * \\
(.047)\end{array}$ & $\begin{array}{l}1.212 * * * \\
(.020)\end{array}$ & $\begin{array}{l}1.239 * * * \\
(.036)\end{array}$ & $\begin{array}{l}1.008 \\
(.050)\end{array}$ \\
\hline Median co-plays & $\begin{array}{l}1.081 * * * \\
(.011)\end{array}$ & $\begin{array}{l}1.063 * * * \\
(.015)\end{array}$ & $\begin{array}{l}1.166^{* * * *} \\
(.012)\end{array}$ & $\begin{array}{l}1.088 * * \\
(.032)\end{array}$ & $\begin{array}{l}1.385 * * * \\
(.042)\end{array}$ & $\begin{array}{l}1.123 * * * \\
(.022)\end{array}$ & $\begin{array}{l}1.151^{* * * *} \\
(.029)\end{array}$ \\
\hline Release history & $\begin{array}{l}1.160 * * * \\
(.011)\end{array}$ & $\begin{array}{l}1.165^{* * * *} \\
(.012)\end{array}$ & $\begin{array}{l}1.280 * * * \\
(.013)\end{array}$ & $\begin{array}{l}1.238 * * * \\
(.031)\end{array}$ & $\begin{array}{l}1.722 * * * \\
(.071)\end{array}$ & $\begin{array}{l}1.861 * * * \\
(.031)\end{array}$ & $\begin{array}{l}2.322 * * * \\
(.409)\end{array}$ \\
\hline Distinctiveness & $\begin{array}{l}.931 * * \\
(.011)\end{array}$ & $\begin{array}{l}1.037 \\
(.031)\end{array}$ & $\begin{array}{l}.671 * * * \\
(.020)\end{array}$ & $\begin{array}{l}.789 * * \\
(.068)\end{array}$ & $\begin{array}{l}1.144 * * * \\
(.025)\end{array}$ & $\begin{array}{l}.659 * * * \\
(.037)\end{array}$ & $\begin{array}{l}.445 * * * \\
(.073)\end{array}$ \\
\hline Year trend & $\begin{array}{l}.991 * * * \\
(.001)\end{array}$ & $\begin{array}{l}.972 * * * \\
(.001)\end{array}$ & $\begin{array}{l}.975 * * * \\
(.001)\end{array}$ & $\begin{array}{l}1.095^{* * * *} \\
(.010)\end{array}$ & $\begin{array}{l}.992 * * * \\
(.001)\end{array}$ & $\begin{array}{l}.960 * * * \\
(.002)\end{array}$ & $\begin{array}{l}.966 * * * \\
(.004)\end{array}$ \\
\hline Constant & $\begin{array}{l}.120 * * * \\
(.009)\end{array}$ & $\begin{array}{l}.216^{* * * *} \\
(.020)\end{array}$ & $\begin{array}{l}.190 * * * \\
(.016)\end{array}$ & $\begin{array}{l}.000 * * * \\
(.000)\end{array}$ & $\begin{array}{l}26.004 * * * \\
(2.223)\end{array}$ & $\begin{array}{l}.082 * * * \\
(.014)\end{array}$ & $\begin{array}{l}.007 * * * \\
(.003)\end{array}$ \\
\hline $\begin{array}{l}N \\
R^{2} \\
\mathrm{AIC} \\
\mathrm{BIC}\end{array}$ & $\begin{array}{c}71,691 \\
.066 \\
34,333 \\
34,407\end{array}$ & $\begin{array}{r}71,694 \\
.077 \\
18,858 \\
18,931\end{array}$ & $\begin{array}{l}23,579 \\
23,652\end{array}$ & $\begin{array}{r}22,299 \\
.053 \\
3,507 \\
3,571\end{array}$ & $\begin{array}{r}61,104 \\
.033 \\
8,839 \\
8,913\end{array}$ & $\begin{array}{c}71,817 \\
.377 \\
7,170 \\
7,244\end{array}$ & $\begin{array}{c}61,104 \\
.133^{3} \\
1,754 \\
1,827\end{array}$ \\
\hline
\end{tabular}

Notes: 1: Coefficients from maximum likelihood models with logistic function. Standard errors are in parentheses.

2: Penalized maximum likelihood models with rare events correction (fit statistics are from refitted ML model).

3: Adjusted McFadden pseudo R-squared reported.

$*: \mathrm{p}<0.05 ; * *: \mathrm{p}<0.01 ; * * *: \mathrm{p}<0.001$

Table SI 10: Models for the relationship between closed triads and seven measures of success, including deep success. Point estimates for "Closed open triads density" are presented on Figure 4, column four, in the main text of the article. 


\begin{tabular}{|c|c|c|c|c|}
\hline & \multicolumn{4}{|c|}{ I. NEA Award } \\
\hline & 1: original $^{1}$ & 1b: band level ${ }^{2}$ & 2: original $^{1}$ & 2b: band level ${ }^{2}$ \\
\hline $\begin{array}{l}\text { Forbidden triads density }>0 \text {, } \\
\text { and } Z \geq 2\end{array}$ & $\begin{array}{l}1.227 * * * \\
(.060)\end{array}$ & $\begin{array}{l}11.792 * * * \\
(2.539)\end{array}$ & & \\
\hline Forbidden triads density $=0$ & $\begin{array}{l}.996 \\
(.038)\end{array}$ & $\begin{array}{l}.955 \\
(.150)\end{array}$ & & \\
\hline $\begin{array}{l}\text { Forbidden triads depth }>0 \text {, } \\
\text { and } Z \geq 2\end{array}$ & & & $\begin{array}{l}1.138 \\
(.457)\end{array}$ & $\begin{array}{c}117.153 * * * \\
(.702)\end{array}$ \\
\hline Forbidden triads depth $=0$ & & & $\begin{array}{l}.931^{*} \\
(.032)\end{array}$ & $\begin{array}{l}.547 * * * \\
(.073)\end{array}$ \\
\hline $\mathrm{N}$ musicians & $\begin{array}{l}.993 * * * \\
(.002)\end{array}$ & $\begin{array}{l}.989 \\
(.014)\end{array}$ & $\begin{array}{l}.991 * * * \\
(.002)\end{array}$ & $\begin{array}{l}.976 \\
(.015)\end{array}$ \\
\hline Session tenure & $\begin{array}{l}1.001 * * * \\
(.000)\end{array}$ & $\begin{array}{l}1.002 * * * \\
(.000)\end{array}$ & $\begin{array}{l}1.001 * * * \\
(.000)\end{array}$ & $\begin{array}{l}1.002 * * * \\
(.000)\end{array}$ \\
\hline Median co-plays & $\begin{array}{l}1.015 * * * \\
(.003)\end{array}$ & $\begin{array}{l}1.058 * * \\
(.019)\end{array}$ & $\begin{array}{l}1.016^{* * * *} \\
(.003)\end{array}$ & $\begin{array}{l}1.065 * * \\
(.021)\end{array}$ \\
\hline Release history & $\begin{array}{l}3.162 * * * \\
(.120)\end{array}$ & $\begin{array}{l}9.127 * * * \\
(1.356)\end{array}$ & $\begin{array}{l}3.170 * * * \\
(.121)\end{array}$ & $\begin{array}{l}8.098 * * * \\
(1.158)\end{array}$ \\
\hline Distinctiveness & $\begin{array}{l}.600^{* *} \\
(.111)\end{array}$ & $\begin{array}{l}.286 \\
(.269)\end{array}$ & $\begin{array}{l}.608^{* *} \\
(.112)\end{array}$ & $\begin{array}{l}.367 \\
(.330)\end{array}$ \\
\hline Year trend & $\begin{array}{l}1.004 * * * \\
(.001)\end{array}$ & $\begin{array}{l}1.019 * * * \\
(.004)\end{array}$ & $\begin{array}{l}1.004 * * * \\
(.001)\end{array}$ & $\begin{array}{l}1.017 * * * \\
(.003)\end{array}$ \\
\hline Constant & $\begin{array}{l}.029 * * * \\
(.004)\end{array}$ & $\begin{array}{l}.001 * * * \\
(.001)\end{array}$ & $\begin{array}{l}.031 * * * \\
(.004)\end{array}$ & $\begin{array}{l}.002 * * * \\
(.001)\end{array}$ \\
\hline$N$ & 72,642 & 16,146 & 72,642 & 16,146 \\
\hline$R^{2}$ & $.084^{3}$ & $.142^{3}$ & $.084^{3}$ & $.123^{3}$ \\
\hline $\mathrm{AIC}$ & 34,232 & 1,182 & 34,249 & 1,208 \\
\hline $\mathrm{BIC}$ & 34,315 & 1,251 & 34,332 & 1,276 \\
\hline
\end{tabular}

Notes: The original models are the ones presented in the main text of the article.

1: Coefficients from maximum likelihood models with logistic function. Standard errors are in parentheses.

2: Penalized maximum likelihood models with rare events correction (fit statistics are from refitted ML model).

3: Adjusted McFadden pseudo R-squared reported.

$*: \mathrm{p}<0.05 ; * *: \mathrm{p}<0.01 ; * * *: \mathrm{p}<0.001$

Table SI 11: Full models of structural availability, and alternative specifications for "NEA Award." Corresponds to Table 6 in the main text of the article. 


\begin{tabular}{|c|c|c|c|c|}
\hline & \multicolumn{4}{|c|}{ II. Critics' Poll } \\
\hline & 3: original $^{1}$ & 3b: band level ${ }^{2}$ & 4: original $^{1}$ & $4 \mathrm{~b}$ : band level ${ }^{2}$ \\
\hline $\begin{array}{l}\text { Forbidden triads density }>0 \text {, } \\
\text { and } Z \geq 2\end{array}$ & $\begin{array}{l}1.272 * * \\
(.091)\end{array}$ & $\begin{array}{l}12.743 * * * \\
(3.413)\end{array}$ & & \\
\hline Forbidden triads density $=0$ & $\begin{array}{l}1.176 * * \\
(.065)\end{array}$ & $\begin{array}{l}1.443 \\
(.325)\end{array}$ & & \\
\hline $\begin{array}{l}\text { Forbidden triads depth }>0, \\
\text { and } Z \geq 2\end{array}$ & & & $\begin{array}{l}.925 \\
(.678)\end{array}$ & $\begin{array}{l}30.768 * * * \\
(1.398)\end{array}$ \\
\hline Forbidden triads depth $=0$ & & & $\begin{array}{l}1.091 \\
(.054)\end{array}$ & $\begin{array}{l}.805 \\
(.151)\end{array}$ \\
\hline $\mathrm{N}$ musicians & $\begin{array}{l}1.000 \\
(.003)\end{array}$ & $\begin{array}{l}.992 \\
(.025)\end{array}$ & $\begin{array}{l}.999 \\
(.003)\end{array}$ & $\begin{array}{l}.980 \\
(.027)\end{array}$ \\
\hline Session tenure & $\begin{array}{l}1.001 * * * \\
(.000)\end{array}$ & $\begin{array}{l}1.002 * * * \\
(.000)\end{array}$ & $\begin{array}{l}1.001 * * * \\
(.000)\end{array}$ & $\begin{array}{l}1.001 * * * \\
(.000)\end{array}$ \\
\hline Median co-plays & $\begin{array}{l}1.014 * * * \\
(.004)\end{array}$ & $\begin{array}{l}1.058 * * \\
(.018)\end{array}$ & $\begin{array}{l}1.014 * * * \\
(.004)\end{array}$ & $\begin{array}{l}1.062 * * \\
(.018)\end{array}$ \\
\hline Release history & $\begin{array}{l}2.361 * * * \\
(.133)\end{array}$ & $\begin{array}{l}7.142^{* * *} \\
(1.636)\end{array}$ & $\begin{array}{l}2.367 * * * \\
(.133)\end{array}$ & $\begin{array}{l}6.670^{* * *} \\
(1.454)\end{array}$ \\
\hline Distinctiveness & $\begin{array}{l}1.489 \\
(.375)\end{array}$ & $\begin{array}{c}3.583 \\
(4.678)\end{array}$ & $\begin{array}{l}1.508 \\
(.380)\end{array}$ & $\begin{array}{l}3.975 \\
(5.011)\end{array}$ \\
\hline Year trend & $\begin{array}{l}.979 * * * \\
(.001)\end{array}$ & $\begin{array}{c}.991 \\
(.006)\end{array}$ & $\begin{array}{l}.979 * * * \\
(.001)\end{array}$ & $\begin{array}{c}.991 \\
(.006)\end{array}$ \\
\hline Constant & $\begin{array}{l}.048 * * * \\
(.008)\end{array}$ & $\begin{array}{l}.001 * * * \\
(.001)\end{array}$ & $\begin{array}{l}.052 * * * \\
(.009)\end{array}$ & $\begin{array}{l}.001 * * * \\
(.001)\end{array}$ \\
\hline$N$ & 72,255 & 16,145 & 72,255 & 16,145 \\
\hline$R^{2}$ & $.078^{3}$ & $.121^{3}$ & $.078^{3}$ & $.106^{3}$ \\
\hline AIC & 19,199 & 663 & 19,210 & 675 \\
\hline $\mathrm{BIC}$ & 19,282 & 733 & 19,293 & 744 \\
\hline
\end{tabular}

Notes: The original models are the ones presented in the main text of the article.

1: Coefficients from maximum likelihood models with logistic function. Standard errors are in parentheses.

2: Penalized maximum likelihood models with rare events correction (fit statistics are from refitted ML model).

3: Adjusted McFadden pseudo R-squared reported.

$*: \mathrm{p}<0.05 ; * *: \mathrm{p}<0.01 ; * * *: \mathrm{p}<0.001$

Table SI 12: Full models of structural availability, and alternative specifications for "Critics' Poll." Corresponds to Table 6 in the main text of the article. 


\begin{tabular}{|c|c|c|c|c|}
\hline & \multicolumn{4}{|c|}{ III. Readers’ Poll } \\
\hline & 5: original $^{1}$ & $5 \mathrm{c}$ : band level ${ }^{3}$ & 6: original ${ }^{1}$ & 6c: band level ${ }^{3}$ \\
\hline $\begin{array}{l}\text { Forbidden triads density }>0 \text {, } \\
\text { and } Z \geq 2\end{array}$ & $\begin{array}{l}1.225 * * \\
(.047)\end{array}$ & $\begin{array}{l}11.241 * * * \\
(2.809)\end{array}$ & & \\
\hline Forbidden triads density $=0$ & $\begin{array}{l}1.029 \\
(.048)\end{array}$ & $\begin{array}{c}.882 \\
(.142)\end{array}$ & & \\
\hline $\begin{array}{l}\text { Forbidden triads depth }>0 \text {, } \\
\text { and } Z \geq 2\end{array}$ & & & $\begin{array}{l}1.717 \\
(.790)\end{array}$ & $\begin{array}{l}582.920 * * * \\
(543.171)\end{array}$ \\
\hline Forbidden triads depth $=0$ & & & $\begin{array}{l}.967 \\
(.040)\end{array}$ & $\begin{array}{l}.541 * * * \\
(.086)\end{array}$ \\
\hline $\mathrm{N}$ musicians & $\begin{array}{l}.985 * * * \\
(.003)\end{array}$ & $\begin{array}{l}1.009 \\
(.015)\end{array}$ & $\begin{array}{l}.983 * * * \\
(.003)\end{array}$ & $\begin{array}{l}.999 \\
(.017)\end{array}$ \\
\hline Session tenure & $\begin{array}{l}1.001 * * * \\
(.000)\end{array}$ & $\begin{array}{l}1.001 * * * \\
(.000)\end{array}$ & $\begin{array}{l}1.001 * * * \\
(.000)\end{array}$ & $\begin{array}{l}1.001 * * * \\
(.000)\end{array}$ \\
\hline Median co-plays & $\begin{array}{l}1.040 * * * \\
(.003)\end{array}$ & $\begin{array}{l}1.097 * * \\
(.033)\end{array}$ & $\begin{array}{l}1.041 * * * \\
(.003)\end{array}$ & $\begin{array}{l}1.101 * * \\
(.037)\end{array}$ \\
\hline Release history & $\begin{array}{l}3.826 * * * \\
(.198)\end{array}$ & $\begin{array}{l}13.419^{* * *} \\
(2.715)\end{array}$ & $\begin{array}{l}3.836 * * * \\
(.199)\end{array}$ & $\begin{array}{l}12.265 * * * \\
(2.451)\end{array}$ \\
\hline Distinctiveness & $\begin{array}{l}.042 * * * \\
(.010)\end{array}$ & $\begin{array}{l}.064 \\
(.094)\end{array}$ & $\begin{array}{l}.043 * * * \\
(.010)\end{array}$ & $\begin{array}{l}.083 \\
(.118)\end{array}$ \\
\hline Year trend & $\begin{array}{l}.983 * * * \\
(.001)\end{array}$ & $\begin{array}{l}1.004 \\
(.005)\end{array}$ & $\begin{array}{l}.984 * * * \\
(.001)\end{array}$ & $\begin{array}{l}1.003 \\
(.005)\end{array}$ \\
\hline Constant & $\begin{array}{l}.340 * * * \\
(.057)\end{array}$ & $\begin{array}{l}.002 * * * \\
(.002)\end{array}$ & $\begin{array}{l}.361 * * * \\
(.057)\end{array}$ & $\begin{array}{l}.004 * * * \\
(.003)\end{array}$ \\
\hline$N$ & 72,381 & 16,146 & 72,381 & 16,146 \\
\hline$R^{2}$ & .135 & .170 & .135 & .154 \\
\hline AIC & 23,710 & 638 & 23,720 & 650 \\
\hline $\mathrm{BIC}$ & 23,793 & 707 & 23,803 & 719 \\
\hline
\end{tabular}

Notes: The original models are the ones presented in the main text of the article.

1: Coefficients from maximum likelihood models with logistic function. Standard errors are in parentheses.

2: Coefficients from maximum likelihood models with logistic function. Independent variables are standardized.

3: Penalized maximum likelihood models with rare events correction (fit statistics are from refitted ML model).

4: Adjusted McFadden pseudo R-squared reported.

$*: \mathrm{p}<0.05 ; * *: \mathrm{p}<0.01 ; * * *: \mathrm{p}<0.001$

Table SI 13: Full models of structural availability, and alternative specifications for "Readers' Poll." Corresponds to Table 6 in the main text of the article. 


\begin{tabular}{|c|c|c|c|c|}
\hline & \multicolumn{4}{|c|}{ IV. Book mention 1940-1969 } \\
\hline & 7: original $^{1}$ & $\begin{array}{c}\text { 7b: zero } \\
\text { inflated } \mathrm{NB}^{2}\end{array}$ & $8:$ original $^{1}$ & $\begin{array}{c}\text { 8b: zero } \\
\text { inflated } \mathrm{NB}^{2}\end{array}$ \\
\hline $\begin{array}{l}\text { Forbidden triads density }>0 \text {, } \\
\text { and } Z \geq 2\end{array}$ & $\begin{array}{l}.945 \\
(.160)\end{array}$ & $\begin{array}{l}-.024 \\
(.226)\end{array}$ & & \\
\hline Forbidden triads density $=0$ & $\begin{array}{l}.770 \\
(.115)\end{array}$ & $\begin{array}{l}-.214 \\
(.186)\end{array}$ & & \\
\hline $\begin{array}{l}\text { Forbidden triads depth }>0 \text {, } \\
\text { and } Z \geq 2\end{array}$ & & & $\begin{array}{c}2.937 \\
(1.877)\end{array}$ & $\begin{array}{l}1.258 \\
(.985)\end{array}$ \\
\hline Forbidden triads depth $=0$ & & & $\begin{array}{l}.803 \\
(.111)\end{array}$ & $\begin{array}{l}-.182 \\
(.166)\end{array}$ \\
\hline $\mathrm{N}$ musicians & $\begin{array}{l}.955^{*} \\
(.018)\end{array}$ & $\begin{array}{l}.028 \\
(.020)\end{array}$ & $\begin{array}{l}.958^{*} \\
(.018)\end{array}$ & $\begin{array}{l}.031 \\
(.020)\end{array}$ \\
\hline Session tenure & $\begin{array}{l}1.000 \\
(.000)\end{array}$ & $\begin{array}{l}-.001 * * \\
(.000)\end{array}$ & $\begin{array}{l}1.000 \\
(.000)\end{array}$ & $\begin{array}{l}-.001 * * \\
(.000)\end{array}$ \\
\hline Median co-plays & $\begin{array}{l}1.016 \\
(.011)\end{array}$ & $\begin{array}{l}.043^{*} \\
(.021)\end{array}$ & $\begin{array}{l}1.015 \\
(.011)\end{array}$ & $\begin{array}{l}.044^{*} \\
(.021)\end{array}$ \\
\hline Release history & $\begin{array}{l}4.812 * * * \\
(.975)\end{array}$ & $\begin{array}{l}-.077 \\
(.332)\end{array}$ & $\begin{array}{l}4.793 * * * \\
(.971)\end{array}$ & $\begin{array}{l}-.089 \\
(.332)\end{array}$ \\
\hline Distinctiveness & $\begin{array}{l}.184^{*} \\
(.158)\end{array}$ & $\begin{array}{l}-1.712 \\
(1.270)\end{array}$ & $\begin{array}{c}.184^{*} \\
(.158)\end{array}$ & $\begin{array}{l}-1.628 \\
(1.273)\end{array}$ \\
\hline Year trend & $\begin{array}{l}1.099 * * * \\
(.012)\end{array}$ & $\begin{array}{l}-.136 * * * \\
(.024)\end{array}$ & $\begin{array}{l}1.099 * * * \\
(.012)\end{array}$ & $\begin{array}{l}-.140 * * * \\
(.024)\end{array}$ \\
\hline Constant & $\begin{array}{l}.000 * * * \\
(.000)\end{array}$ & $\begin{array}{l}7.956^{* * *} \\
(1.666)\end{array}$ & $\begin{array}{l}.000 * * * \\
(.000)\end{array}$ & $\begin{array}{l}8.187 * * * \\
(1.678)\end{array}$ \\
\hline $\begin{array}{l}N \\
R^{2}\end{array}$ & $\begin{array}{r}22,820 \\
.068^{3}\end{array}$ & 22,820 & $\begin{array}{r}22,820 \\
.069^{3}\end{array}$ & 22,820 \\
\hline AIC & 3,515 & 4,532 & 3,512 & 4,530 \\
\hline $\mathrm{BIC}$ & 3,587 & 4,669 & 3,584 & 4,667 \\
\hline
\end{tabular}

Notes: The original models are the ones presented in the main text of the article.

1: Coefficients from penalized maximum likelihood models with rare events correction (fit statistics are from refitted ML model). Standard errors clustered for band are in parentheses.

2: Coefficients from the count model of a zero inflated negative binomial regression model. (Vuong test $Z=8.14$, indicating zero

inflation. Inflation model included controls only.)

3: Adjusted McFadden pseudo R-squared reported.

$\dagger: \mathrm{p}=.058^{*}: \mathrm{p}<0.05 ; * *: \mathrm{p}<0.01 ; * * *: \mathrm{p}<0.001$

Table SI 14: Full models of structural availability, and alternative specifications for "Book mention." Corresponds to Table 6 in the main text of the article. 


\begin{tabular}{|c|c|c|c|c|}
\hline & \multicolumn{4}{|c|}{ V. Survival } \\
\hline & 9: original $^{1}$ & $\begin{array}{l}\text { 9b: Cox } \\
\text { regression }\end{array}$ & $10:$ original $^{1}$ & $\begin{array}{l}\text { 10b: Cox } \\
\text { regression }\end{array}$ \\
\hline $\begin{array}{l}\text { Forbidden triads density }>0 \text {, } \\
\text { and } Z \geq 2\end{array}$ & $\begin{array}{c}.939 \\
(.039)\end{array}$ & $\begin{array}{l}.917^{*} \\
(.039)\end{array}$ & & \\
\hline Forbidden triads density $=0$ & $\begin{array}{l}1.033 \\
(.029)\end{array}$ & $\begin{array}{l}1.081 * * \\
(.031)\end{array}$ & & \\
\hline $\begin{array}{l}\text { Forbidden triads depth }>0 \text {, } \\
\text { and } Z \geq 2\end{array}$ & & & $\begin{array}{l}.858 \\
(.351)\end{array}$ & $\begin{array}{l}1.258 \\
(.985)\end{array}$ \\
\hline Forbidden triads depth $=0$ & & & $\begin{array}{l}1.056^{*} \\
(.026)\end{array}$ & $\begin{array}{l}1.114 * * * \\
(.028)\end{array}$ \\
\hline $\mathrm{N}$ musicians & $\begin{array}{l}1.002 \\
(.001)\end{array}$ & $\begin{array}{l}1.004 * \\
(.001)\end{array}$ & $\begin{array}{l}1.003^{*} \\
(.001)\end{array}$ & $\begin{array}{l}1.004 * * \\
(.001)\end{array}$ \\
\hline Session tenure & $\begin{array}{l}1.000 \\
(.000)\end{array}$ & $\begin{array}{l}.999 * * * \\
(.000)\end{array}$ & $\begin{array}{l}1.000 \\
(.000)\end{array}$ & $\begin{array}{l}.999 * * * \\
(.000)\end{array}$ \\
\hline Median co-plays & $\begin{array}{l}1.000 \\
(.004)\end{array}$ & $\begin{array}{l}.995 \\
(.003)\end{array}$ & $\begin{array}{l}1.000 \\
(.004)\end{array}$ & $\begin{array}{l}.995 \\
(.003)\end{array}$ \\
\hline Release history & $\begin{array}{l}.861 * * * \\
(.027)\end{array}$ & $\begin{array}{l}.844 * * * \\
(.026)\end{array}$ & $\begin{array}{l}.861 * * * \\
(.027)\end{array}$ & $\begin{array}{l}.844 * * * \\
(.026)\end{array}$ \\
\hline Distinctiveness & $\begin{array}{l}1.006 \\
(.102)\end{array}$ & $\begin{array}{l}1.168 \\
(.119)\end{array}$ & $\begin{array}{l}1.003 \\
(.102)\end{array}$ & $\begin{array}{l}1.164 \\
(.118)\end{array}$ \\
\hline Year trend & $\begin{array}{l}1.019 * * * \\
(.001)\end{array}$ & $\begin{array}{l}1.010^{* * * *} \\
(.001)\end{array}$ & $\begin{array}{l}1.019 * * * \\
(.001)\end{array}$ & $\begin{array}{l}1.010 * * * \\
(.001)\end{array}$ \\
\hline Structural zero & $\begin{array}{c}.965 \\
(.023)\end{array}$ & $\begin{array}{l}.912 * * * \\
(.022)\end{array}$ & $\begin{array}{c}.967 \\
(.023)\end{array}$ & $\begin{array}{l}.913 * * * \\
(.022)\end{array}$ \\
\hline Constant & $\begin{array}{l}.210^{* * * *} \\
(.019)\end{array}$ & & $\begin{array}{l}.206^{* * * *} \\
(.019)\end{array}$ & \\
\hline$N$ & 97,184 & 97,184 & 97,184 & 97,184 \\
\hline AIC & 49,931 & 221,382 & 49,934 & 221,386 \\
\hline $\mathrm{BIC}$ & 50,112 & 221,467 & 50,114 & 221,472 \\
\hline
\end{tabular}

Notes: The original models are the ones presented in the main text of the article.

1: From piecewise exponential regression models, we report hazard ratios and standard errors (in parentheses).

2: From Cox regression models, we report hazard ratios and standard errors (in parentheses).

$* \mathrm{p}<0.05 ; * * \mathrm{p}<0.01 ; * * * \mathrm{p}<0.001$ (two-tailed).

Table SI 15: Full models of structural availability, and alternative specifications for "Survival." Corresponds to Table 6 in the main text of the article. 


\begin{tabular}{|c|c|c|c|c|}
\hline & \multicolumn{4}{|c|}{ VI. Releases (per decade, log) } \\
\hline & 11: original ${ }^{1}$ & $\begin{array}{c}\text { 11b: zero } \\
\text { inflated NB }\end{array}$ & 12: original ${ }^{1}$ & $\begin{array}{l}\text { 12b: zero } \\
\text { inflated } \mathrm{NB}^{2}\end{array}$ \\
\hline $\begin{array}{l}\text { Forbidden triads density }>0 \text {, } \\
\text { and } \mathrm{Z} \geq 2\end{array}$ & $\begin{array}{l}-.004 \\
(.004)\end{array}$ & $\begin{array}{l}.048 \\
(.034)\end{array}$ & & \\
\hline Forbidden triads density $=0$ & $\begin{array}{l}-.017 * * * \\
(.003)\end{array}$ & $\begin{array}{l}-.058 \\
(.035)\end{array}$ & & \\
\hline $\begin{array}{l}\text { Forbidden triads depth }>0 \text {, } \\
\text { and } Z \geq 2\end{array}$ & & & $\begin{array}{l}.003 \\
(.032)\end{array}$ & $\begin{array}{l}-.063 \\
(.241)\end{array}$ \\
\hline Forbidden triads depth $=0$ & & & $\begin{array}{l}-.016^{* * * *} \\
(.003)\end{array}$ & $\begin{array}{l}-.073 \\
(.032)\end{array}$ \\
\hline $\mathrm{N}$ musicians & $\begin{array}{l}.002 * * * \\
(.000)\end{array}$ & $\begin{array}{l}.009^{*} \\
(.004)\end{array}$ & $\begin{array}{l}.002 * * * \\
(.000)\end{array}$ & $\begin{array}{l}.009 * \\
(.004)\end{array}$ \\
\hline Session tenure & $\begin{array}{l}-.000 * * * \\
(.000)\end{array}$ & $\begin{array}{l}-.001 \\
(.000)\end{array}$ & $\begin{array}{l}-.000 * * * \\
(.000)\end{array}$ & $\begin{array}{l}-.001 \\
(.000)\end{array}$ \\
\hline Median co-plays & $\begin{array}{l}-.000 \\
(.000)\end{array}$ & $\begin{array}{l}.004 \\
(.003)\end{array}$ & $\begin{array}{l}-.000 \\
(.000)\end{array}$ & $\begin{array}{l}.004 \\
(.003)\end{array}$ \\
\hline Release history & $\begin{array}{l}.236^{* * *} \\
(.004)\end{array}$ & $\begin{array}{l}1.270^{* * * *} \\
(.068)\end{array}$ & $\begin{array}{l}.236^{* * *} \\
(.005)\end{array}$ & $\begin{array}{l}1.270^{* * * *} \\
(.068)\end{array}$ \\
\hline Distinctiveness & $\begin{array}{l}-.120^{* * *} \\
(.021)\end{array}$ & $\begin{array}{l}-1.229 * * * \\
(.202)\end{array}$ & $\begin{array}{l}-.120 * * * \\
(.021)\end{array}$ & $\begin{array}{l}-1.229 * * * \\
(.202)\end{array}$ \\
\hline Year trend & $\begin{array}{l}.006 * * * \\
(.000)\end{array}$ & $\begin{array}{l}-.043 * * * \\
(.002)\end{array}$ & $\begin{array}{l}.006 * * * \\
(.000)\end{array}$ & $\begin{array}{l}-.043 * * * \\
(.002)\end{array}$ \\
\hline Constant & $\begin{array}{l}-.781 * * * \\
(.031)\end{array}$ & $\begin{array}{l}3.246^{* * * *} \\
(.173)\end{array}$ & $\begin{array}{l}-.783 * * * \\
(.031)\end{array}$ & $\begin{array}{l}3.263 * * * \\
(.172)\end{array}$ \\
\hline $\begin{array}{l}N \\
R^{2}\end{array}$ & $\begin{array}{r}71,817 \\
.111^{3}\end{array}$ & 71,817 & $\begin{array}{c}71,817 \\
.111^{3}\end{array}$ & 71,817 \\
\hline AIC & & 162,475 & & 162,479 \\
\hline BIC & & 162,631 & & 162,635 \\
\hline
\end{tabular}

Notes: The original models are the ones presented in the main text of the article.

1: Coefficients from penalized maximum likelihood models with rare events correction (fit statistics are from refitted ML model). Standard errors clustered for band are in parentheses.

2: Coefficients from zero inflated negative binomial count model for the number of additional releases, with clustered standard errors for band. Inflation model omitted (featured control variables only).

3: R-squared for within-band model.

$\dagger: \mathrm{p}=.058^{*}: \mathrm{p}<0.05 ; * *: \mathrm{p}<0.01 ; * * * \mathrm{p}<0.001$

Table SI 16: Full models of structural availability, and alternative specifications for "Releases." Corresponds to Table 6 in the main text of the article. 